\title{
Empirical Validation Procedure for the Knowledge Management Technology Stage Model
}

\author{
Petter Gottschalk \\ Norwegian School of Management, Sandvika, Norway \\ petter.gottschalk@bi.no
}

\begin{abstract}
Stages of growth models have been used widely in both organizational research and information technology management research. However, stages of growth models are criticized for lack of empirical validity. This paper develops a survey instrument to empirically validate a knowledge management technology stage model. The survey instrument has several parts that enable cross-examination of responses. One important instrument part is concerned with Guttman scaling which is a cumulative scaling technique.
\end{abstract}

Keywords: validation, Guttman scaling, survey instrument, knowledge management, information technology, stages of growth model, law firms.

\section{Introduction}

Stages of growth models have been used widely in both organizational research and information technology management research. According to King and Teo (1997), these models describe a wide variety of phenomena - the organizational life cycle, product life cycle, biological growth, etc. These models assume that predictable patterns (conceptualized in terms of stages) exist in the growth of organizations, the sales levels of products, and the growth of living organisms. These stages are (1) sequential in nature, (2) occur as a hierarchical progression that is not easily reversed, and (3) involve a broad range of organizational activities and structures.

Stages of growth models are criticized for lack of empirical validity. Benbasat et al. (1984) found that most of the benchmark variables for stages used by Nolan (1979) were not confirmed in empirical studies. Based on empirical evidence, Benbasat et al. (1984) wrote the following critique of Nolan's stage hypothesis:

The stage hypothesis on the assimilation of computing technology provides one of the most popular models for describing and managing the growth of administrative information systems. Despite little formal evidence of its reliability or robustness, it has achieved a high level of acceptance among practitioners. We describe and summarize the findings of seven em-

Material published as part of this journal, either on-line or in print, is copyrighted by the publisher of Informing Science. Permission to make digital or paper copy of part or all of these works for personal or classroom use is granted without fee provided that the copies are not made or distributed for profit or commercial advantage AND that copies 1) bear this notice in full and 2) give the full citation on the first page. It is permissible to abstract these works so long as credit is given. To copy in all other cases or to republish or to post on a server or to redistribute to lists requires specific permission and payment of a fee. Contact Editor@inform.nu to request redistribution permission. pirical studies conducted during the past six years that tested various hypotheses derived from this model. The accumulation of evidence from these studies casts considerable doubt on the validity of the stage hypothesis as an explanatory structure for the growth of computing in organizations.

For example, Nolan (1979) proposed that steering committees should be constituted in later stages of maturity. However, an empirical study showed that of 114 firms, 64 of which had steering committees, the correlation between IT maturity and steering committees was not significant. Organizations in practice adopt steering committees throughout the development cycle rather than in the later stages.

Another example is charge-back methods. In a survey, approximately half of the firms used charge-back systems and the other half did not. In the Nolan (1979) structure, as firms mature through later stages, they should have adopted charge-back systems. Yet, in the empirical analysis, there were no significant correlations between maturity indicators and charge-back system usage, according to Benbasat et al. (1984). Benchmark variables such as steering committees and charge-back systems have to be carefully selected and tested before they are applied in survey research.

The concept of stages of growth has created a number of skeptics. Some argue that the concept of an organization progressing uni-directionally through a series of predictable stages is overly simplistic. For example, organizations may evolve through periods of convergence and divergence related more to shifts in information technology than to issues of growth for specific IT. According to Kazanjian and Drazin (1989), it can be argued that firms do not necessarily demonstrate any inexorable momentum to progress through a linear sequence of stages, but rather 
that observed configurations of problems, strategies, structures and processes will determine firm evolution.

Kazanjian and Drazin (1989) addressed the need for further data-based research to empirically examine whether organizations in a growth environment shift according to a hypothesized stage of growth model or follow a more random pattern of change that would be associated with shifts in configurations that did not follow such progression.

Based on a sample of 71 firms they found support for the stage hypothesis.

To meet the criticism of lack of empirical validity, this research paper describes the careful development, selection and testing of a variety of instrument parts to empirically validate a knowledge management technology stage model.

\section{The KMT Stage Model}

The knowledge management technology (KMT) stage model consists of four stages (Gottschalk 2002). The first stage is general IT support for knowledge workers. This includes word processing, spreadsheets, and email. The second stage is information about knowledge sources. An information system stores information on who knows what in the firm and outside the firm. The system does not store what they actually know. A typical example is the company intranet. The third stage is information representing knowledge. The system stores what knowledge workers know in terms of information. A typical example is a database. The fourth and final stage is information processing. An information system uses information to evaluate situations. A typical example is an expert system.
The contingent approach to firm performance implies that Stage I may be right for one firm, while Stage IV may be right for another firm. Some firms will evolve over time from Stage I to higher stages. A law firm moving from Stage II to Stage III is illustrated in Figure 1.

Stages of IT support in knowledge management are useful to identify the current situation as well as to plan for future applications in the firm. Each stage is described in the following:

1. End user tools are made available to knowledge workers. At the simplest stage, this means a capable networked PC on every desk or in every briefcase, with standardized personal productivity tools (word processing, presentation software) so that documents can be exchanged easily throughout a company. More complex and functional desktop infrastructures can also be the basis for the same types of knowledge support. Stage $I$ is recognized by widespread dissemination and use of end-user tools among knowledge workers in the company. For example, lawyers in a law firm will at this stage use word processing, spreadsheet, legal databases, presentation software, and scheduling programs.

2. Information about who knows what is made available to all people in the firm and to selected outside partners. Search engines should enable work with a thesaurus, since the terminology in which expertise is sought may not always match the terms the expert uses to classify that expertise. According to Alavi and Leidner (2001), the creation of corporate directories, also referred to as the mapping of internal expertise, is a common application of knowledge management technology. Because much knowledge in an

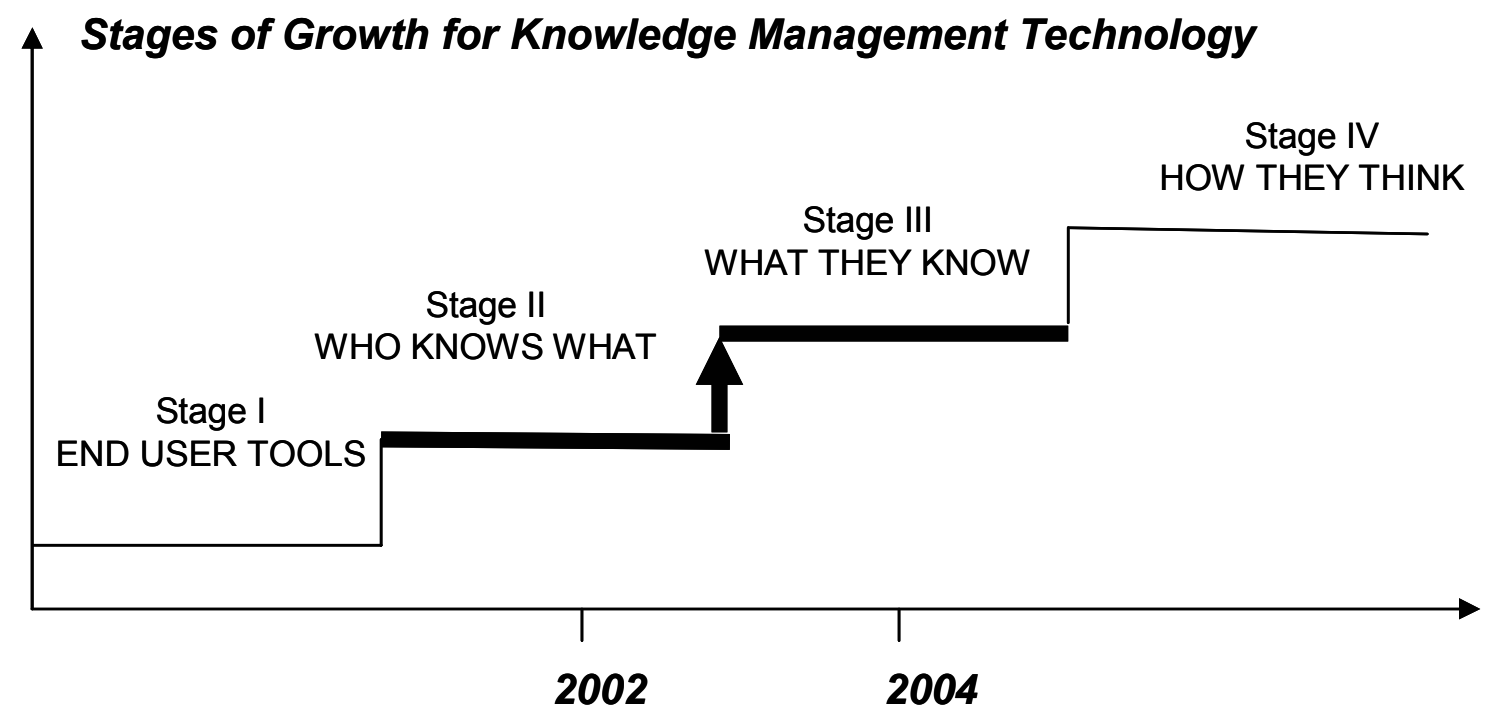

Figure 1. The Stages of Growth Model for Knowledge Management Technology 
nology. Because much knowledge in an organization remains uncodified, mapping the internal expertise is a potentially useful application of technology to enable easy identification of knowledgeable persons. Here we find the cartographic school of knowledge management (Earl 2001), which is concerned with mapping organizational knowledge. It aims to record and disclose who in the organization knows what by building knowledge directories. Often called Yellow Pages, the principal idea is to make sure knowledgeable people in the organization are accessible to others for advice, consultation, or knowledge exchange. Knowledgeoriented directories are not so much repositories of knowledge-based information as gateways to knowledge, and the knowledge is as likely to be tacit as explicit. Information about who knows what is sometimes called metadata, representing knowledge about where the knowledge resides. Providing taxonomies or organizational knowledge maps enables individuals to rapidly locate the individual who has the needed knowledge, more rapidly than would be possible without such IT-based support. One starting approach at Stage II is to store curriculum vitae (CV) for each knowledge worker in the firm. Areas of expertise, projects completed and clients helped may over time expand the CV. For example, a lawyer in a law firm works on cases for clients using different information sources that can be registered on yellow pages in terms of an intranet. The creation of a knowledge network is an important part of Stage II. Unless specialists can communicate easily with each other across platform types, expertise will deteriorate. People have to be brought together both virtually and face-to-face to exchange and build their collective knowledge in each of the specialty areas. The knowledge management effort is focused on bringing the experts together so that important knowledge can be shared and amplified, rather than on mapping expertise or benchmarking that occurs at Stage III. According to Earl (2001), knowledge directories represent more of a belief in personalized knowledge of individuals than the codified knowledge of knowledge bases and may demonstrate organizational preferences for human, not technology-mediated, communication and exchange. The knowledge philosophy of firms that settle at Stage II can be seen as one of people connectivity. Consequently, the principal contribution from IT is to connect people via intranets and to help them locate knowledge sources and providers using directories accessed by the intranet. Extranets and the Internet may connect knowledge workers to external knowledge sources and providers.

3. Information from knowledge workers is stored and made available to all people in the firm and to selected outside partners. Here data mining techniques can be applied to find relevant information and combine in- formation in data warehouses. On a broader basis, search engines are web browsers and server software that work with a thesaurus, since the terminology in which expertise is sought may not always match the terms the expert uses to classify that expertise. One starting approach at Stage III is to store project reports, notes, recommendations and letters from each knowledge worker in the firm. Over time, this material will grow fast, making it necessary for a librarian or a chief knowledge officer (CKO) to organize it. In a law firm, all client cases will be classified and stored in databases using software such as Lotus Notes. An essential contribution that IT can make is the provision of shared databases across tasks, levels, entities, and geographies to all knowledge workers throughout a process (Earl, 2001). According to Alavi and Leidner (2001), one survey found that $74 \%$ of respondents believed that their organization's best knowledge was inaccessible and $68 \%$ thought that mistakes were reproduced several times. Such perception of failure to apply existing knowledge is an incentive for mapping, codifying and storing information derived from internal expertise. According to Alavi and Leidner (2001), one of the most common applications is internal benchmarking with the aim of transferring internal best practices. To be successful, best practices have to be coded, stored and shared among knowledge workers. In addition to (i) best practices knowledge within a quality or business process management function, other common applications include (ii) knowledge for sales purposes involving products, markets and customers, (iii) lessons learned in projects or product development efforts, (iv) knowledge around implementation of information systems, (v) competitive intelligence for strategy and planning functions, and (vi) learning histories or records of experience with a new corporate direction or approach (Grover and Davenport, 2001). At Stage III, access both to knowledge (expertise, experience, and learning) and to information (intelligence, feedback, and data analyses) is provided by systems and intranets to operatives, staff, and executives. The supply and distribution of knowledge and information are not restricted. Whereas we might say at Stage I, "give knowledge workers the tools to do the job", we now add, "give knowledge workers the knowledge and information to do the job". According to Earl (2001), this is another way of saying that the philosophy is enhancing the firm's capabilities with knowledge flows. Although most knowledge repositories serve a single function, Grover and Davenport (2001) found that it is increasingly common for companies to construct an internal portal so that employees can access multiple different repositories and sources from one screen. It is also possible and increasingly popular for repositories to contain information as well as pointers to experts within the organization on key knowledge topics. Often 
called Knowledge Yellow Pages, these systems facilitate contact and knowledge transfer between knowledgeable people and those who seek their knowledge. Stored, codified knowledge is combined with lists of individuals who contributed the knowledge and could provide more detail or background on it. According to Grover and Davenport (2001), firms increasingly view attempts to transform raw data into usable knowledge as part of their knowledge management initiatives. These approaches typically involve isolating data in a separate warehouse for easier access and the use of statistical analysis or data mining and visualization tools. Since their goal is to create data-derived knowledge, they are increasingly addressed as part of knowledge management at Stage III.

4. Information systems solving knowledge problems are made available to knowledge workers and solution seekers. Artificial intelligence is applied in these systems. For example, neural networks are statistically oriented tools that excel at using data to classify cases into one category or another. Another example is expert systems that can enable the knowledge of one or a few experts to be used by a much broader group of workers who need the knowledge. According to Alavi and Leidner (2001), an insurance company was faced with the commoditization of its market and declining profits. The company found that applying the best decision making expertise via a new underwriting process supported by a knowledge management system based on best practices enabled it to move into profitable niche markets and, hence, to increase income. According to Grover and Davenport (2001), artificial intelligence is applied in rule-based systems, and more commonly, case-based systems are used to capture and provide access to customer service problem resolution, legal knowledge, new product development knowledge, and many other types. Expert system is an example of knowledge management technology at Stage IV. According to Curtis and Cobham (2002), the short answer is that an expert system is a computerized system that performs the role of an expert or carries out a task that requires expertise. In order to understand what an expert system is, then, it is worth paying attention to the role of an expert and the nature of expertise. It is then important to ascertain what types of expert and expertise there are in business and what benefits will accrue to an organization when it develops an expert system. For example, a doctor having a knowledge of diseases comes to a diagnosis of an illness by reasoning from information given by the patient's symptoms and then prescribes medication on the basis of known characteristics of available drugs together with the patient's history. The lawyer advises the client on the likely outcome of litigation based on the facts of the particular case, an expert understanding of the law and knowl- edge of the way the courts work and interpret this law in practice. The accountant looks at various characteristics of a company's performance and makes a judgment as to the likely state of health of that company (Curtis and Cobham 2002). All of these tasks involve some of the features for which computers traditionally have been noted - performing text and numeric processing quickly and efficiently - but they also involve one more ability: reasoning. Reasoning is the movement from details of a particular case and knowledge of the general subject area surrounding that case to the derivation of conclusions. Expert systems incorporate this reasoning by applying general rules in an information base to aspects of a particular case under consideration (Curtis and Cobham 2002).

When companies want to use knowledge in real-time, mission-critical applications, they have to structure the information base for rapid, precise access. A web search yielding hundreds of documents will not suffice when a customer is waiting on the phone for an answer. Representing and structuring knowledge is a requirement that has long been addressed by artificial intelligence researchers in the form of expert systems and other applications. Now their technologies are being applied in the context of knowledge management. Rule-based systems and case-based systems are used to capture and provide access to customer service problem resolution, legal knowledge, new product development knowledge, and many other types. Although it can be difficult and labor-intensive to author a structured knowledge base, the effort can pay off in terms of faster responses to customers, lower cost per knowledge transaction, and lessened requirements for experienced, expert personnel (Grover and Davenport 2001).

Expert systems are at stage IV in the proposed model. Stewart (1997) argues for stage II by stating that knowledge grows so fast that any attempt to codify it all is ridiculous; but the identities of in-house experts change slowly. Corporate yellow pages should be easy to construct, but it's remarkable how few companies have done it. A simple system that connects inquirers to experts save time, reduces error and guesswork, and prevents the reinvention of countless wheels.

What could be stored at Stage III, according to Stewart (1997), are lessons learned and competitor intelligence. A key way to improve knowledge management is to bank lessons learned - in effect, checklists of what went right and wrong, together with guidelines for others undertaking similar projects. In the area of competitor intelligence, companies need to organize knowledge about their suppliers, customers, and competitors. 


\section{Research Instrument}

Empirical validation of the Stages of Growth can be carried out through a survey using a questionnaire as listed in Appendix C.

In the second part of the survey instrument in Appendix C, there are four research constructs defined, one for each stage. Each construct is measured through a multiple-item scale. Each scale has five items, where the fifth item is a summary item. For each responding law firm, the average value for each level can be calculated. For the whole sample, statistical difference tests such as the t-test can be applied to evaluate whether responding law firms report significant differences between stages. Empirical validation of the Stages of Growth will be successful if responding law firms have significantly lower scores at higher levels.

In the fourth part of the survey instrument in Appendix C, the four stages of growth are described in terms of bench- mark variables. Benchmark variables indicate the theoretical characteristics at each stage of growth (King and Teo 1997). For example, firms at Stage I can theoretically be expected to conform to values of benchmark variables listed under Stage I. However, this does not mean that it is not possible for firms at Stage I to have values of benchmark variables applicable to other stages. Rather, it means that the values of benchmark variables indicate the most likely theoretical characteristics applicable at each stage of integration as indicated in Table 1.

There are a total of thirty-two benchmark variables in Table 1. Fifteen benchmark variables (1-15) are concerned with IT in KM; the next six benchmark variables (16-21) are concerned with IT management, while the remaining eleven (22-32) are concerned with knowledge management in general.

Benchmark variables indicate the theoretical characteristics at each stage of growth. The problem with this ap-

\begin{tabular}{|c|c|c|c|c|c|c|}
\hline No. & $\begin{array}{l}\text { Benchmark } \\
\text { Variable }\end{array}$ & $\begin{array}{l}\text { Stage I } \\
\text { END USER } \\
\text { TOOLS }\end{array}$ & $\begin{array}{l}\text { Stage II } \\
\text { WHO KNOWS } \\
\text { WHAT }\end{array}$ & $\begin{array}{l}\text { Stage III } \\
\text { WHAT THEY } \\
\text { THINK }\end{array}$ & $\begin{array}{l}\text { Stage IV } \\
\text { HOW THEY THINK }\end{array}$ & Inspired by \\
\hline 1 & $\begin{array}{l}\text { Trigger of IT for } \\
K M\end{array}$ & $\begin{array}{l}\text { Individual law- } \\
\text { yer's needs for } \\
\text { tools }\end{array}$ & $\begin{array}{l}\text { Organization's } \\
\text { needs for informa- } \\
\text { tion }\end{array}$ & $\begin{array}{l}\text { Automate lawyers' } \\
\text { information work }\end{array}$ & $\begin{array}{l}\text { Automate lawyers' } \\
\text { knowledge work }\end{array}$ & $\begin{array}{l}\text { King and } \\
\text { Teo } 1997\end{array}$ \\
\hline 2 & $\begin{array}{l}\text { Top manage- } \\
\text { ment's partici- } \\
\text { pation }\end{array}$ & Rarely & Sometimes & Frequently & Almost always & $\begin{array}{l}\text { King and } \\
\text { Teo } 1997\end{array}$ \\
\hline 3 & $\begin{array}{l}\text { User manage- } \\
\text { ment's partici- } \\
\text { pation }\end{array}$ & Rarely & Sometimes & Frequently & Almost always & $\begin{array}{l}\text { King and } \\
\text { Teo } 1997\end{array}$ \\
\hline 4 & $\begin{array}{l}\text { Principal contri- } \\
\text { bution }\end{array}$ & $\begin{array}{l}\text { Efficiency of } \\
\text { lawyer }\end{array}$ & $\begin{array}{l}\text { Effectiveness of } \\
\text { lawyer }\end{array}$ & $\begin{array}{l}\text { Effectiveness of } \\
\text { firm }\end{array}$ & $\begin{array}{l}\text { Competitiveness of } \\
\text { firm }\end{array}$ & $\begin{array}{l}\text { Gottschalk } \\
2002\end{array}$ \\
\hline 5 & $\begin{array}{l}\text { Technology } \\
\text { assessment }\end{array}$ & Rarely & Sometimes & Frequently & Almost always & $\begin{array}{l}\text { King and } \\
\text { Teo } 1997\end{array}$ \\
\hline 6 & Focus & Availability & Reorganization & Culture & Replacement & $\begin{array}{l}\text { Gottschalk } \\
2002\end{array}$ \\
\hline 7 & $\begin{array}{l}\text { Dominating } \\
\text { statement }\end{array}$ & $\begin{array}{l}\text { Distribute infor- } \\
\text { mation }\end{array}$ & $\begin{array}{l}\text { Produce docu- } \\
\text { mentation }\end{array}$ & Make decisions & Automate work & $\begin{array}{l}\text { Gottschalk } \\
2002\end{array}$ \\
\hline 8 & Philosophy & Client satisfaction & $\begin{array}{l}\text { Knowledge com- } \\
\text { munity }\end{array}$ & $\begin{array}{l}\text { Lawyer independ- } \\
\text { ence }\end{array}$ & $\begin{array}{l}\text { Client independ- } \\
\text { ence }\end{array}$ & $\begin{array}{l}\text { Susskind } \\
2000 \\
\text { Grover and } \\
\text { Davenport } \\
2001\end{array}$ \\
\hline 9 & $\begin{array}{l}\text { Critical success } \\
\text { factor }\end{array}$ & $\begin{array}{l}\text { PCs and net- } \\
\text { works }\end{array}$ & $\begin{array}{l}\text { Knowledge man- } \\
\text { agement systems }\end{array}$ & $\begin{array}{l}\text { Quality and quan- } \\
\text { tity }\end{array}$ & $\begin{array}{l}\text { Culture and incen- } \\
\text { tives }\end{array}$ & $\begin{array}{l}\text { Gottschalk } \\
2002\end{array}$ \\
\hline 10 & Strategy & Tool strategy & Stock strategy & Flow strategy & Growth strategy & $\begin{array}{l}\text { Hansen } \\
1999\end{array}$ \\
\hline 11 & Main task & Distributing & Capturing & Sharing & Applying & $\begin{array}{l}\text { Gottschalk } \\
2002\end{array}$ \\
\hline 12 & Main purpose & $\begin{array}{l}\text { Administrative } \\
\text { work }\end{array}$ & $\begin{array}{l}\text { Access to infor- } \\
\text { mation }\end{array}$ & $\begin{array}{l}\text { Sharing informa- } \\
\text { tion }\end{array}$ & Automating work & $\begin{array}{l}\text { Gottschalk } \\
2002\end{array}$ \\
\hline 13 & $\begin{array}{l}\text { Main applica- } \\
\text { tions }\end{array}$ & Office support & $\begin{array}{l}\text { Customer rela- } \\
\text { tions }\end{array}$ & $\begin{array}{l}\text { Knowledge man- } \\
\text { agement }\end{array}$ & Online web advice & $\begin{array}{l}\text { Susskind } \\
2000\end{array}$ \\
\hline 14 & Attitude & Skeptics & Conservatives & Early adopters & Innovators & Tiwana 2001 \\
\hline 15 & $\begin{array}{l}\text { Value shop ac- } \\
\text { tivity }\end{array}$ & $\begin{array}{l}\text { Understanding } \\
\text { clients' problem }\end{array}$ & $\begin{array}{l}\text { Implementing } \\
\text { solution }\end{array}$ & $\begin{array}{l}\text { Solving clients' } \\
\text { problem }\end{array}$ & $\begin{array}{l}\text { Selecting optimal } \\
\text { solution }\end{array}$ & $\begin{array}{l}\text { Stabell and } \\
\text { Fjeldstad } \\
1997\end{array}$ \\
\hline
\end{tabular}




\begin{tabular}{|c|c|c|c|c|c|c|}
\hline 16 & $\begin{array}{l}\text { Contribution of } \\
\text { IT function }\end{array}$ & Supplier of PCs & $\begin{array}{l}\text { Technical infra- } \\
\text { structure }\end{array}$ & $\begin{array}{l}\text { Resource of in- } \\
\text { formation }\end{array}$ & Supplier of systems & $\begin{array}{l}\text { King and } \\
\text { Teo } 1997\end{array}$ \\
\hline 17 & $\begin{array}{l}\text { Role of IT man- } \\
\text { ager }\end{array}$ & $\begin{array}{l}\text { Technology ex- } \\
\text { pert }\end{array}$ & $\begin{array}{l}\text { Functional admin- } \\
\text { istrator }\end{array}$ & $\begin{array}{l}\text { Resource man- } \\
\text { ager }\end{array}$ & $\begin{array}{l}\text { Knowledge man- } \\
\text { agement expert }\end{array}$ & $\begin{array}{l}\text { King and } \\
\text { Teo } 1997\end{array}$ \\
\hline 18 & $\begin{array}{l}\text { Performance of } \\
\text { IT function }\end{array}$ & $\begin{array}{l}\text { Operational effi- } \\
\text { ciency }\end{array}$ & $\begin{array}{l}\text { Business imple- } \\
\text { mentation }\end{array}$ & $\begin{array}{l}\text { Knowledge im- } \\
\text { plementation }\end{array}$ & Long-term impact & $\begin{array}{l}\text { King and } \\
\text { Teo } 1997\end{array}$ \\
\hline 19 & $\begin{array}{l}\text { Key issue for IT } \\
\text { function }\end{array}$ & $\begin{array}{l}\text { Personal com- } \\
\text { puters }\end{array}$ & Data processing & $\begin{array}{l}\text { Information sys- } \\
\text { tems }\end{array}$ & $\begin{array}{l}\text { Information net- } \\
\text { works }\end{array}$ & Nolan 1979 \\
\hline 20 & $\begin{array}{l}\text { IT manager's } \\
\text { participation }\end{array}$ & Rarely & Sometimes & Frequently & Almost always & $\begin{array}{l}\text { King and } \\
\text { Teo } 1997\end{array}$ \\
\hline 21 & $\begin{array}{l}\text { Status of IT } \\
\text { executive }\end{array}$ & Three or more & Two & One & One with access & $\begin{array}{l}\text { King and } \\
\text { Teo } 1997\end{array}$ \\
\hline 22 & Business level & Availability-driven & Efficiency-driven & $\begin{array}{l}\text { Effectiveness- } \\
\text { driven }\end{array}$ & Expert-driven & $\begin{array}{l}\text { Hansen } \\
1999\end{array}$ \\
\hline 23 & Main effect & $\begin{array}{l}\text { Reduced de- } \\
\text { pendence }\end{array}$ & $\begin{array}{l}\text { Effective applica- } \\
\text { tion }\end{array}$ & New knowledge & Client performance & $\begin{array}{l}\text { Gottschalk } \\
2002\end{array}$ \\
\hline 24 & $\begin{array}{l}\text { Priority in busi- } \\
\text { ness }\end{array}$ & Fourth & Third & Second & First & $\begin{array}{l}\text { Gottschalk } \\
2002\end{array}$ \\
\hline 25 & $\begin{array}{l}\text { Management } \\
\text { agenda }\end{array}$ & Year & Month & Week & Day & $\begin{array}{l}\text { Gottschalk } \\
2002\end{array}$ \\
\hline 26 & $\begin{array}{l}\text { Priority in mar- } \\
\text { keting }\end{array}$ & Fourth & Third & Second & First & $\begin{array}{l}\text { Susskind } \\
2000\end{array}$ \\
\hline 27 & Normal work & $\begin{array}{l}\text { User-friendly } \\
\text { experience }\end{array}$ & $\begin{array}{l}\text { Efficiently organ- } \\
\text { ized }\end{array}$ & $\begin{array}{l}\text { Innovative solu- } \\
\text { tions }\end{array}$ & $\begin{array}{l}\text { III-specified prob- } \\
\text { lems }\end{array}$ & $\begin{array}{l}\text { Hansen } \\
1999\end{array}$ \\
\hline 28 & $\begin{array}{l}\text { Knowledge } \\
\text { growth }\end{array}$ & Know-what & Know-why & $\begin{array}{l}\text { Know-how to } \\
\text { solve }\end{array}$ & $\begin{array}{l}\text { Know-how client } \\
\text { solve }\end{array}$ & Tiwana 2001 \\
\hline 29 & $\begin{array}{l}\text { Knowledge } \\
\text { characteristics }\end{array}$ & Experts dictate & $\begin{array}{l}\text { Some knowledge } \\
\text { explicated }\end{array}$ & $\begin{array}{l}\text { Documented in } \\
\text { methodology }\end{array}$ & $\begin{array}{l}\text { Well explicated } \\
\text { knowledge }\end{array}$ & Tiwana 2001 \\
\hline 30 & $\begin{array}{l}\text { Status of } K M \\
\text { executive }\end{array}$ & Three or more & Two & One & $\begin{array}{l}\text { One with direct } \\
\text { access }\end{array}$ & $\begin{array}{l}\text { King and } \\
\text { Teo } 1997\end{array}$ \\
\hline 31 & $\begin{array}{l}\text { Response time } \\
\text { to clients }\end{array}$ & One week & One day & One hour & One minute & Voss 2000 \\
\hline 32 & $\begin{array}{l}\text { Response qual- } \\
\text { ity }\end{array}$ & Less than $50 \%$ & $50 \%$ to $89 \%$ & $90 \%$ to $95 \%$ & More than 95\% & Voss 2000 \\
\hline
\end{tabular}

\section{Table 1 Typology of Evolutionary Stages}

proach is that all indicators of a stage may not be present in an organization, which makes it difficult to place the organization in any specific stage. Unfortunately, IT factors do not lend themselves to precise Guttman scaling techniques (Frankfort-Nachmias and Nachmias, 2002; Nunnally and Bernstein, 1994).

Guttman scaling is also sometimes known as cumulative scaling or scalogram analysis. Guttman scaling is based on ordering theory that suggests a linear relationship between the elements of a domain and the items on a test. The purpose of Guttman scaling is to establish a one-dimensional continuum for a concept to measure. We would like a set of items or statements so that a respondent who agrees with any specific question in the list will also agree with all previous questions. This is the ideal for a stage model or for any progression. By that we mean that it is useful when one progresses from one state to another state in a manner so that if one is in the later/higher stage, it also indicates that one has all the features of the earlier stage (Trochim, 2002).
For example, a cumulative model for knowledge transfer could consist of six stages: awareness, familiarity, attempt to use, utilization, results, and impact. Byers and Byers (1998) developed a Guttman scale for knowledge levels consisting of stages by order of learning difficulty. Trochim (2002) developed the following cumulative six-stage scale for attitudes towards immigration:

1. I believe that this country should allow more immigrants in

2. I would be comfortable with new immigrants moving into my community

3. It would be fine with me if new immigrants moved onto my block

4. I would be comfortable if a new immigrant moved next door to me

5. I would be comfortable if my child dated a new immigrant

6. I would permit a child of mine to marry an immigrant 
Guttman (1950) used scalogram analysis successfully during the war in investigating morale and other problems in the United States Army. In scalogram analysis, items are ordered such that, ideally, organizations that answer a given question favorably all have higher ranks than organizations that answer the same question unfavorably. According to Guttman (1950, p. 62), the ranking of organizations provides a general approach to the problem of scaling:

\section{We shall call a set of items of common content a scale if an organization with a higher rank than another organization is just as high or higher on every item than the other organiza- tion.}

In the current research, benchmark variable number 13 may serve as a problematic Guttman scaling example. Based on Susskind's (2000) legal grid, the variable suggests that there is a progression from office support, via customer relationships and knowledge management, to legal web advice. This progression may vary among firms, thereby making such a standard progression questionable. Nevertheless, this benchmark variable was included to enable empirical measurement of the legal grid.

The next benchmark variable, number 14, may serve as another example. Based on Tiwana's (2001) proposal that there are skeptics, conservatives, early adopters and innovators, this classification was introduced as a scale.

The last benchmark variables 31 and 32 are derived from Tiwana (2001) who suggested the existence of both stages of knowledge growth and stages of knowledge characteristics.

Benchmark variables in Table 1 indicate theoretical characteristics that commonly occur together. Sabherwal and Chan (2001) label this configuration, where a configuration is defined as any multidimensional constellation of conceptually distinct characteristics that commonly occur together. Configurations take a step beyond the traditional contingency theoretic view by using a holistic rather than a reductionistic stance. They offer richer insights by focusing on parsimonious and relatively homogeneous groups rather than diverse concepts.

In the fifth part of the survey instrument in Appendix C, the four stages of growth are extensively described, enabling respondents to make an overall judgment of knowledge management technology stage in the firm.

In the sixth part of the survey instrument, a validation check of the paths of evolution is conducted. Respondents are asked to indicate the duration spent at each stage of growth. This is to ensure that respondents do think about paths of evolution (King and Teo, 1997). The duration (number of years) spent at each stage is also measured in the questionnaire.

In the seventh part of the survey instrument, knowledgesharing perceptions, reward perceptions, support for personal development, as well as appraisal perceptions are measured as defined by Hunter and Beaumont (2002). This is done to evaluate a theoretical proposition that higher stages of growth will have higher knowledgesharing perceptions, higher reward perceptions, better support for personal development, and higher appraisal perceptions.

In the eight and final part of the survey instrument, strategy and responsibility questions are applied to identify intentions and focus based on content analysis of responses. This is done to evaluate a theoretical proposition that higher stages of growth will be associated with more IT and KM focused strategy statements as well as more IT and KM executives (Hunter and Beaumont, 2002).

The desired informant for this proposed survey instrument is the chief executive officer (CEO) who can be the managing partner or the managing director in a law firm.

\section{Pilot Test of Research Instrument}

According to Boudreau et al. (2001), an instrument pilot test is important in information technology management research. A pilot test is a brief preliminary survey, often using a small, convenience sample. The pilot tests the instrumentation before survey details are finalized and the larger, final survey administered. The pilot is conducted to ensure that there are no unanticipated difficulties.

A convenience sample of law firms was used for the pilot test of the stages of growth questionnaire. The convenience sample consisted of the following five law firms in Norway: Lindh Stabell Horten, Ræder, Simonsen Føyen, Schjødt, and Wiersholm Mellbye \& Bech. These firms reported that they had an average of 151 employees, out of which 102 were lawyers. The pilot was conducted in July 2002.

The second part of the questionnaire measures the extent of systems use in the four categories. On average, the five pilot firms reported 4.9 on the end-user-tools scale, 3.4 on the who-knows-what scale, 2.6 on the what-they-know scale, and 1.0 on the how-they-think scale. These average scores indicate clearly that there are stages of growth, as the scores are declining systematically at higher stages. As the average number on a scale from 1 to 6 is 3.5, a possible interpretation of the scores at each stage is that the firms on average are at Stage II as the score 3.4 on this scale is close to 3.5 . 
In the fourth part of the survey instrument, the four stages of growth are described in terms of benchmark variables. Benchmark variables indicate the theoretical characteristics at each stage of growth. Firms in the convenience sample had an average score of 2.6 on all benchmark variables, again indicating Stage II.

Trochim (2002) recommends that Guttman scales should be subject to expert rating before they are exposed to respondent rating. The expert rating is concerned with developing a cumulative scale, while the respondent rating is concerned with applying a cumulative scale. Trochim (2002) recommends having a group of expert judges rate the statements in terms of how favorable they are to each concept. Expert judges are not asked whether they personally agree with the statement. Instead, they are asked to make a judgment about how the statement is related to the construct of interest. This procedure was first explored for only one of the benchmark variables. The seventh benchmark variable is concerned with the dominating statement about knowledge management technology among lawyers. For this variable, three expert judges rated 'make decisions' as more advanced than 'produce documentation', leading to changes in the scale for this benchmark variable as listed in Table 1 and in Appendix C.

The expert judge procedure was then applied for the whole set of benchmark variables in two iterations. The first iteration consisted of four faculty members who rated statements on a Likert scale as listed in Appendix A. This was done on an individual basis. Then, in a group of fourteen other faculty members, the ratings of statements in Appendix A were discussed.

This second and final iteration with fourteen expert judges was organized as a focus group meeting. First, each of the fourteen participants were asked to rate each of the four statements for each of the twenty-nine benchmark variables individually using a questionnaire. For some benchmark variables, all participants had a systematic result from left to right on their Likert scales. These benchmark variables were left unchanged. For those benchmark variables where respondents disagreed, there was a discussion on the content of each item. Often, a change of word(s) solved the problem, making it possible to leave the item inside the scale. In some cases, an item was so problematic that it had to be replaced by another item suggested by the group.

King and Teo (1997) argue that since the current stage of growth is measured by asking respondents to place a check mark beside one of the four descriptions of the type of stage, it is important to ensure that respondents are actually able to understand and distinguish among the four types. This research tried to make the descriptions and conceptual representations as clear and concise as possible through the expert rating and the pilot test as described above. As a validation check, some pilot test respondents comments were analyzed to determine whether they had any difficulty understanding or distinguishing among the types of stages.

In the fifth part of the survey instrument, the four stages of growth are extensively described, enabling respondents to make an overall judgment of knowledge management technology stage in the firm. The average response here was 3.0, indicating Stage III, rather than Stage II from the systems and benchmark measurements.

In the sixth part of the survey instrument, a validation check of the paths of evolution is conducted. Respondents were asked to indicate the duration spent at each stage of growth. Only one respondent filled in this table. This respondent wrote 2000-2001 next to end-user tools, 2000next to who-knows-what, 1998- next to what-they-know, and NA next to how-they- think.

In the seventh part of the survey instrument, knowledgesharing perceptions, reward perceptions, support for personal development, as well as appraisal perceptions are measured as defined by Hunter and Beaumont (2002). This is done to evaluate a theoretical proposition that higher stages of growth will have higher knowledgesharing perceptions, higher reward perceptions, better support for personal development, and higher appraisal perceptions. The average response for knowledge-sharing was 3.1 , which is very close to neither agreeing nor disagreeing. The average response for reward perceptions was 3.7 , which indicates some agreement.

This pilot test of the questionnaire revealed several unanticipated difficulties. In the second part measuring the extent of systems use in four categories, several difficulties occurred. An item concerned with 'internal standards database' was first placed at the what-they-know stage. This item achieved a high score in most firms, higher than other items at Stage III. An investigation into this item revealed that an internal standards database in a law firm typically has 500-900 standard documents represented as frameworks rather than cases. While a case belongs to Stage III, a framework belongs to Stage II. A framework does not belong to Stage I, as it is not only a tool. A standard document will contain information about lawyers who have previously applied the document, thereby justifying the who-knows-what stage.

In the fourth part of the survey instrument applying benchmark variables, some variables were revised and some variables were added. For example, the statement 'please indicate the frequency of top management's participation in knowledge management' was changed to 'please indicate the frequency of top management's participation 
in information technology planning for knowledge management', ensuring that the technology dimension is not forgotten by respondents. While there were ten benchmark variables in the pilot test, the final survey instrument has thirty-two variables to ensure that data analysis will be possible based on a subset of all benchmark variables.

In the fifth part of the survey instrument describing extensively the four stages of growth, no changes were made, as they seem to capture the essence of each stage. No changes were made, even though the average response in the pilot was 3.0, indicating Stage III, rather than Stage II from the systems and benchmark measurements. All benchmark variables are described in Appendix B.

The remaining parts of the survey instrument were not modified because of few responses. The lack of responses was due to the fact the first pilot firms only got the first few parts of the questionnaire.

This indicates an evolutionary approach to questionnaire development, influenced by both recent research literature and pilot firms' responses. The final questionnaire has six parts in Appendix $\mathrm{C}$ that are designed to measure stage of growth in a law firm. The six measurements will be linked for each law firm to determine what stage the firm is at, as well as to determine the uncertainty of assigning the firm to one specific stage.

\section{References}

Afuah, A. and Tucci, C.L. (2001), Internet Business Models and Strategies, USA: McGraw-Hill.

Alavi, M and Leidner, D E (2001), "Knowledge Management and Knowledge Management Systems: Conceptual Foundations and Research Issues", MIS Quarterly, 25 (1), pp. 107-136.

Becker, W M; Herman, M F; Samuelson, P A and Webb, A P (2001), "Lawyers get down to business", The McKinsey Quarterly, 2001 (2), pp. 45-55.

Benbasat, I; Dexter, A S; Drury, D H and Goldstein, R C (1984), "A Critique of the Stage Hypothesis: Theory and Empirical Evidence", Communications of the ACM, 27 (5), pp. 476-485.

Boudreau, M C; Gefen, D. and Straub, D W (2001), "Validation in Information Systems Research: A State-of-the-Art Assessment", MIS Quarterly, 25 (1), pp. 1-16.

Byers, C and Byers, W A (1998), "Sliding scale: A technique to optimize the assessment of knowledge level through ordering theory", Annual Conference of the International Personnel Management Association Assessment Council, Chicago, June, http://www.ipmaac.org/conf98/byers.pdf

Curtis, G and Cobham, D (2002), Business Information Systems: Analysis, Design and Practice, UK: Prentice Hall.
Davenport, T H and Prusak, L (2000), Working Knowledge, USA: Harvard Business School Press.

Drazin, R and Kazanjian, R K (1990), "A reanalysis of Miller and Friesen's life cycle data", Strategic Management Journal, 11, pp. 319-325.

Drazin, R and Kazanjian, R K (1993), "Applying the del technique to the analysis of cross-classification data: a test of CEO succession and top management team development", Academy of Management Journal, 36 (6), pp. 1374-1399.

Earl, M J (2000), "Evolving the E-business". Business Strategy Review, 11 (2), pp. 33-38.

Earl, M J (2001), "Knowledge Management Strategies: Toward a Taxonomy", Journal of Management Information Systems, 18 (1), pp. 215-233.

Edwards, D L and Mahling, D E (1997), "Toward Knowledge Management Systems in the Legal Domain”, Proceedings of the International ACM SIGGROUP Conference on Supporting Group Work Group '97, USA: The Association of Computing Machinery ACM, pp. 158-166.

Fahey, L and Prusak, L (1998), "The Eleven Deadliest Sins of Knowledge Management", California Management Review, Spring, pp. 9-21.

Feather, S R (1999), "The Impact of Group Support Systems on Collaborative Learning Groups' Stages of Development", Information Technology, Learning, and Performance Journal, 17 (2), Fall, pp. 23-34.

Frankfort-Nachmias, C and Nachmias, D (2002), Research Methods in the Social Sciences, Fifth Edition, UK: Arnold.

Galanter, M and Palay, T (1991), Tournament of Lawyers, The Transformation of the Big Law Firm, USA: The University of Chicago Press.

Gottschalk, P (2002), "Toward a Model of Growth Stages for Knowledge Management Technology in Law Firms", Informing Science, 5 (2), pp. 79-93.

Grover, V and Davenport, T H (2001), “General Perspectives on Knowledge Management: Fostering a Research Agenda", Journal of Management Information Systems (JMIS), 18 (1), pp. 5-21.

Guttman, L (1950), "The Basis for Scalogram Analysis", In: Stouffer, S A; Guttman, L; Suchman, E A; Lazardsfeld, P F; Star, S A and Clausen, J A, Measurement and Prediction, Studies in Social Psychology in World War II, volume IV, USA: Princeton University Press, pp. 60-90.

Hair, J F; Anderson, R E; Tatham, R L and Black, W C (1998), Multivariate Data Analysis, Fifth Edition, USA: Prentice-Hall.

Hansen, M T (1999), "The Search-Transfer Problem: The Role of Weak Ties in Sharing Knowledge across Organizational Subunits", Administrative Science Quarterly, 44, pp. 82-111. 
Hitt, M A; Bierman, L; Shimizu, K and Kochhar, R (2001), "Direct and moderating effects of human capital on strategy and performance in professional service firms: a resource-based perspective", Academy of Management Journal, 44 (1), pp. 13-28

Hunter, L and Beaumont, P (2002), "Knowledge management practice in Scottish law firms", Human Resource Management Journal, 12 (2), pp. 4-21.

Kazanjian, R K (1988), "Relation of dominant problems to stages of growth in technology-based new ventures", Academy of Management Journal, 31 (2), pp. 257-279.

Kazanjian, R K and Drazin, R (1989), "An empirical test of a stage of growth progression model", Management Science, 35 (12), pp. 1489-1503.

King, WR and Teo, TSH (1997), "Integration Between Business Planning and Information Systems Planning: Validating a Stage Hypothesis", Decision Sciences, 28 (2), pp. 279-307.

Mitra, R and Pingali, V (1999), "Analysis of Growth Stages in Small Firms: A Case Study of Automobile Ancillaries in India", Journal of Small Business Management, July, pp. 62-75.

Montana, J C (2000), "The Legal System and Knowledge Management”, The Information Management Journal, July, pp. 54-57.

Mountain, D (2001), "Could New Technologies cause Great Law Firms to Fail?", Journal of Information, Law \& Technology (JILT), issue 1, 9 pages.

Nahapiet, J and Ghoshal, S (1998), "Social capital, intellectual capital, and the organizational advantage", Academy of Management Review, 23 (2), pp. 242-266.

Nunnally, J C and Bernstein, I H (1994), Psychometric Theory, Third Edition, USA: McGraw-Hill.
Sabherwal, R and Chan, Y E (2001), "Alignment Between Business and IS Strategies: A Study of Prospectors, Analyzers, and Defenders", Information Systems Research, 12 (1), pp. 11-33.

Stabell, C.B. and Fjeldstad, Ø.D. (1998), "Configuring Value for Competitive Advantage: On Chains, Shops, and Networks", Strategic Management Journal, 19, pp. 413-437.

Stewart, T A (1997), Intellectual Capital: The New Wealth of Organizations, UK: Nicholas Brealy Publishing.

Susskind, R (2000), Transforming the Law, UK: Oxford University Press.

Tiwana, A (2000), The Knowledge Management Toolkit - Practical Techniques for Building a Knowledge Management System, USA: Prentice Hall.

Tiwana, A (2001), The Essential Guide to Knowledge Management, USA: Prentice Hall.

Trochim (2002), http://trochim.human.cornell.edu/kb/scalgutt.htm

Voss, C. (2000), "Developing an eService Strategy", Business Strategy Review, 11 (1), pp. 21-33.

\section{Biography}

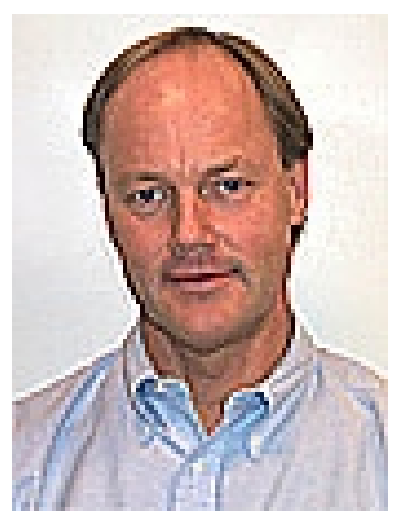

Petter Gottschalk is professor in the Department of Leadership and Organizational Management at the Norwegian School of Management. He has been $\mathrm{CIO}$ at $\mathrm{ABB}$ and CEO of the Norwegian Computing Center. His most recent book is entitled "Knowledge Management through Information Technology".

\section{Appendix A: Expert Survey for Guttman Scaling}

\begin{tabular}{|c|c|c|c|c|c|c|c|c|c|}
\hline $\begin{array}{l}\text { Statements } \\
\text { 1. The implementation of information technol- } \\
\text { ogy for knowledge management is primarily } \\
\text { triggered by: } \\
\quad>\text { consideration of individual lawyers' }\end{array}$ & \multicolumn{9}{|c|}{$\begin{array}{l}\text { little extent } \\
\text { of information technology (IT) in knowl } \\
\text { edge management (KM) in the firm }\end{array}$} \\
\hline $\begin{array}{l}\text { 1. The implementation of information technol- } \\
\text { ogy for knowledge management is primarily } \\
\text { triggered by: } \\
>\text { consideration of individual lawyers' } \\
\text { needs } \\
>\text { consideration of the organization's } \\
\text { needs } \\
>\text { the need to transform the firm by auto- } \\
\text { mating lawyers' information work }\end{array}$ & 1 & 2 & 3 & 4 & 5 & 6 & 2 & 8 & 9 \\
\hline
\end{tabular}




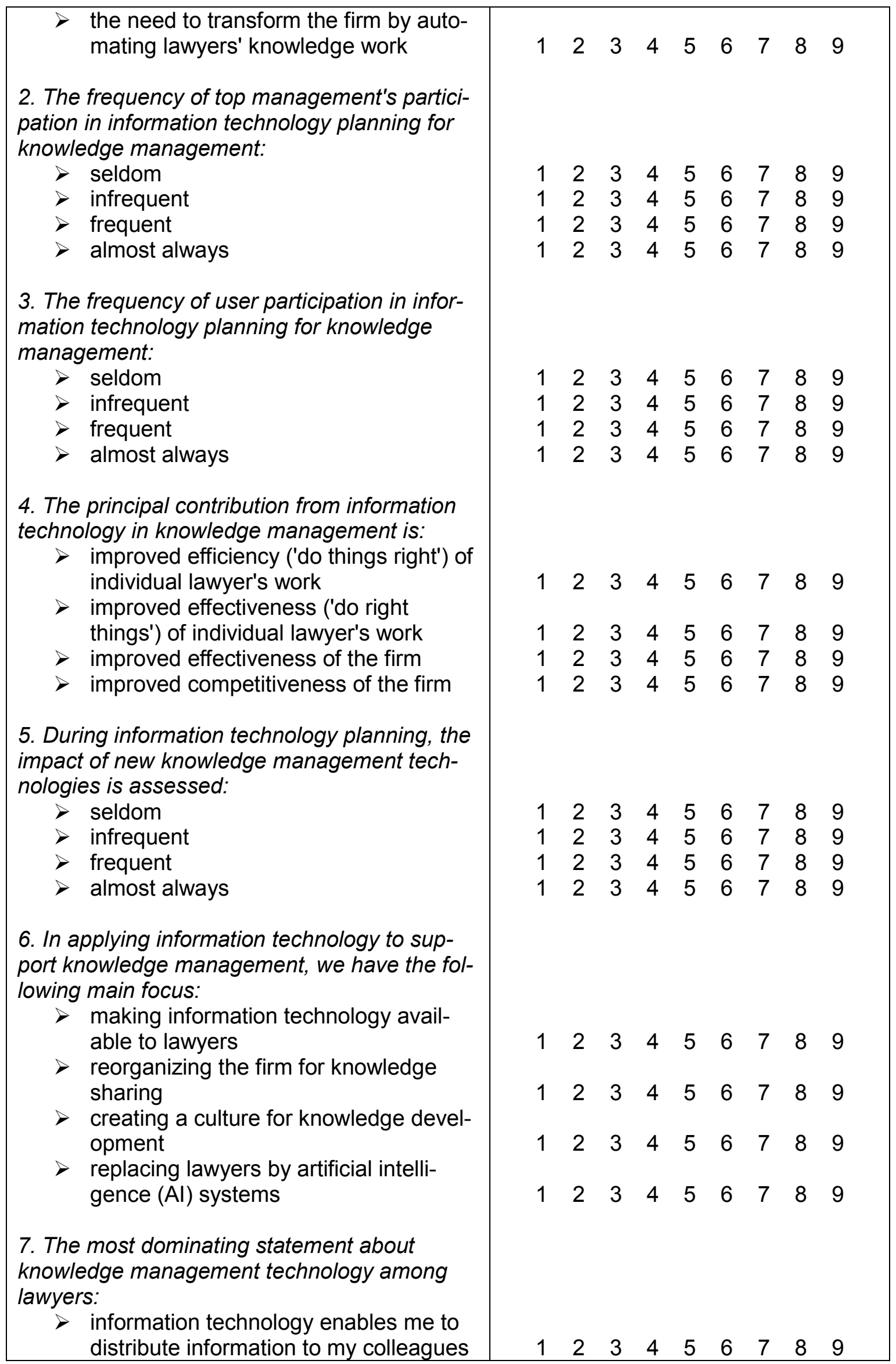




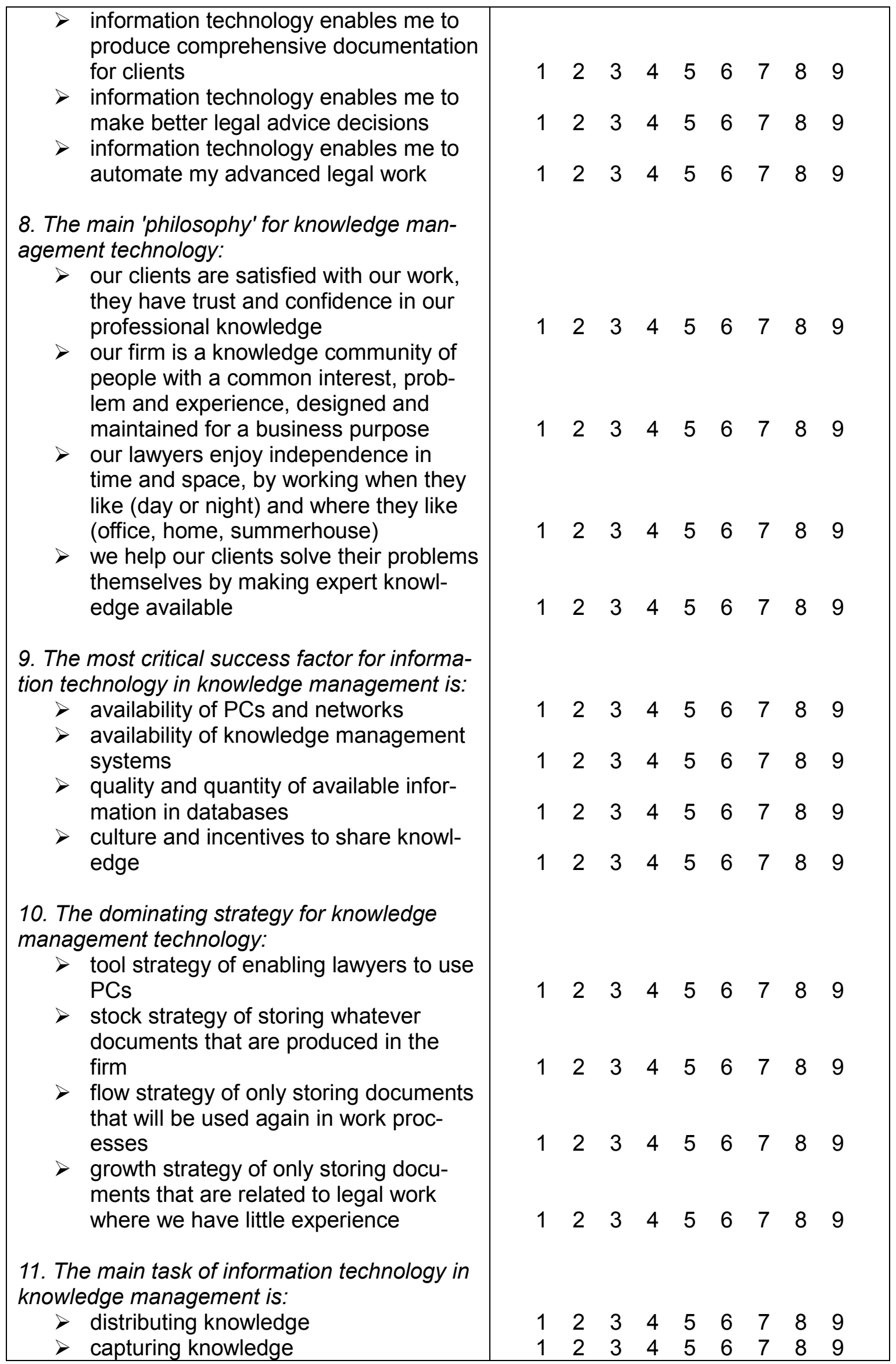




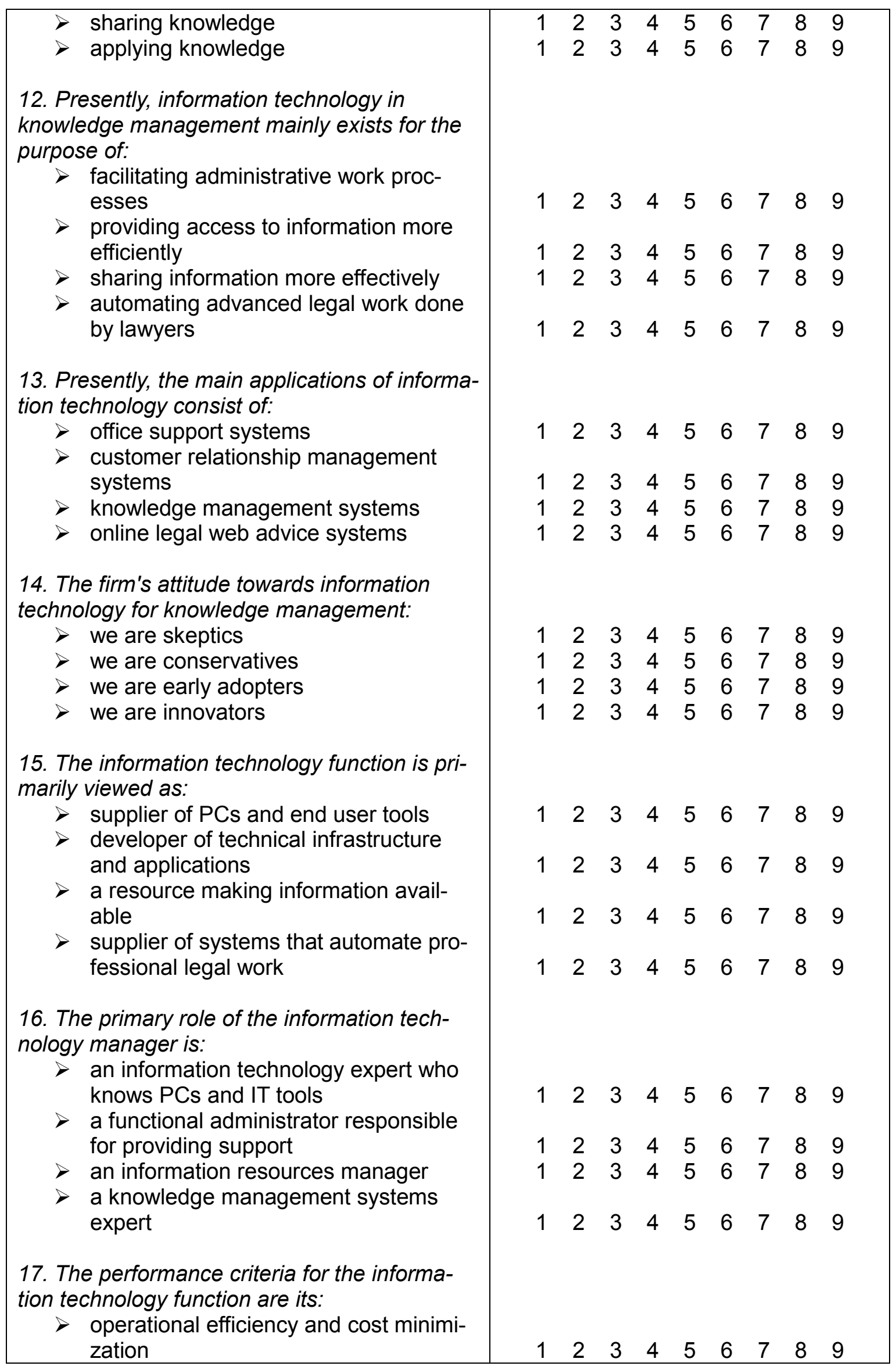




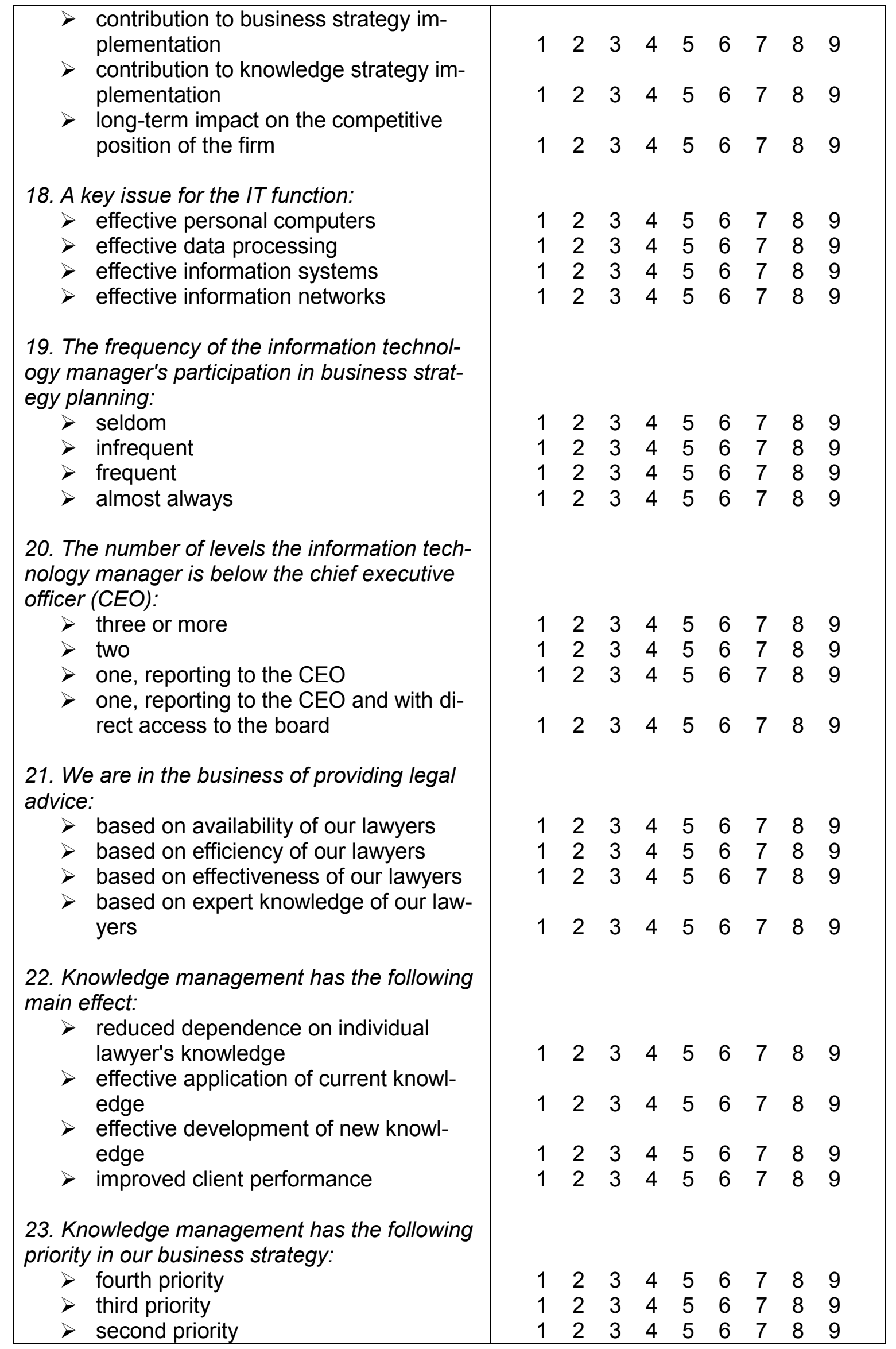




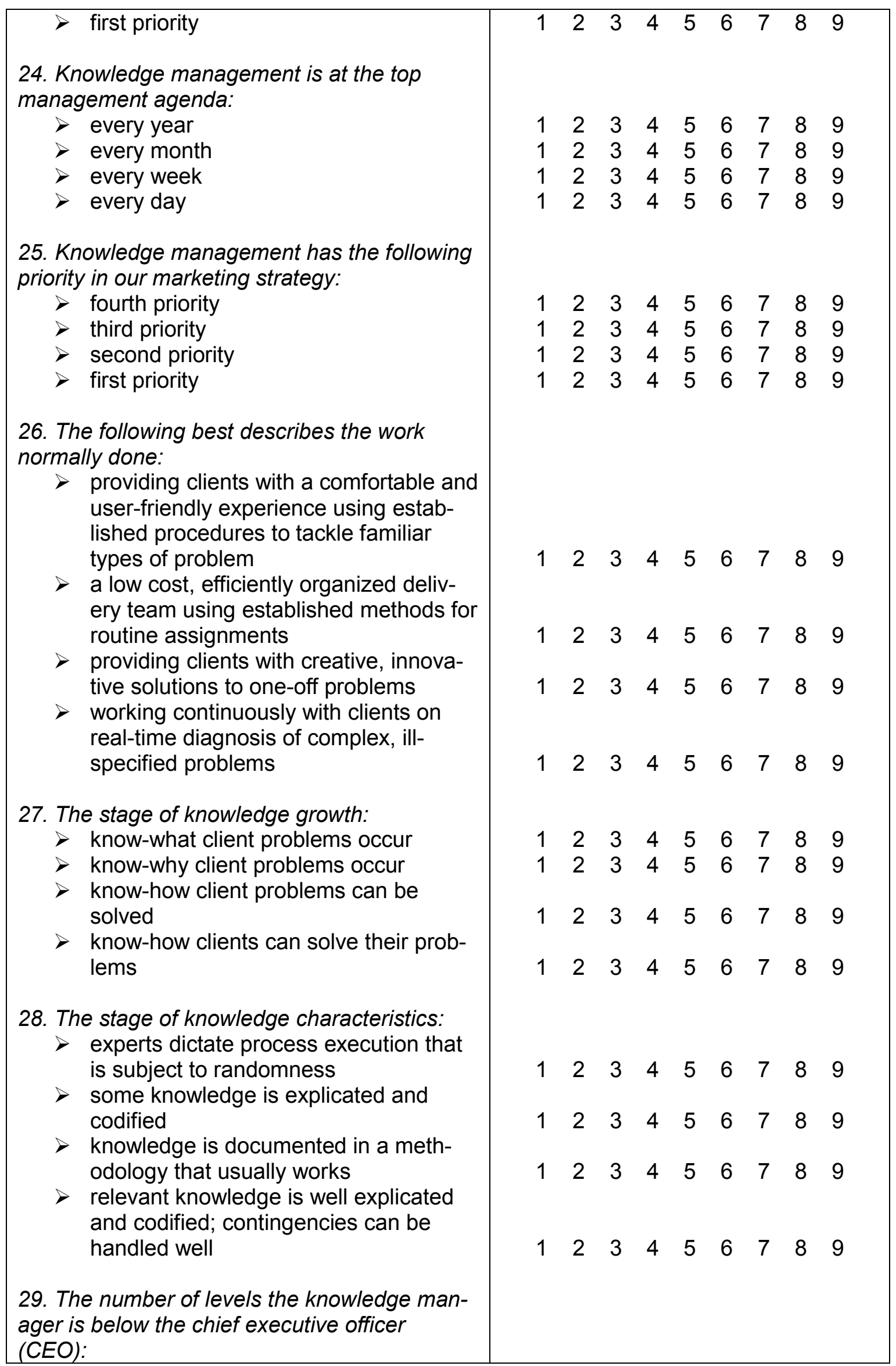




\begin{tabular}{|l|lllllllll|}
\hline$>$ & 1 & 2 & 3 & 4 & 5 & 6 & 7 & 8 & 9 \\
$>$ & 1 & 2 & 3 & 4 & 5 & 6 & 7 & 8 & 9 \\
& 1 & 2 & 3 & 4 & 5 & 6 & 7 & 8 & 9 \\
& $\begin{array}{l}\text { one } \\
\text { one, reporting to the CEO } \\
\text { rect access to the board }\end{array}$ \\
& 1 & 2 & 3 & 4 & 5 & 6 & 7 & 8 & 9
\end{tabular}

\section{Appendix B: Benchmark Variables Using Guttman Scales}

\begin{tabular}{|c|c|c|}
\hline No. & $\begin{array}{l}\text { Benchmark } \\
\text { Variable }\end{array}$ & Description of Benchmark Variable \\
\hline 1 & $\begin{array}{l}\text { Trigger of IT } \\
\text { for knowledge } \\
\text { management }\end{array}$ & $\begin{array}{l}\text { Initially, the triggers for the application of new information technology for knowl- } \\
\text { edge management are opportunities for achieving greater efficiencies based on } \\
\text { individual lawyer's needs (Stage I). As information systems begin to be increas- } \\
\text { ingly used to support business functions, organization needs become trigger } \\
\text { mechanisms in deciding appropriate IT applications to be developed (Stage II). } \\
\text { As information systems begin to be increasingly used to support business } \\
\text { strategies, the need to develop the firm by automating lawyers' information work } \\
\text { becomes an important trigger mechanism (Stage III). Finally, IT is used to trans- } \\
\text { form the firm by automating lawyers' knowledge work (Stage IV). This bench- } \\
\text { mark variable was adapted based on King and Teo's (1997) benchmark variable } \\
5 \text { concerned with triggers for development of information systems (IS) applica- } \\
\text { tions. They found a significant del correlation between this benchmark variable } \\
\text { and stages of integration. }\end{array}$ \\
\hline 2 & $\begin{array}{l}\text { Top manage- } \\
\text { ment's partici- } \\
\text { pation in IT } \\
\text { planning for } \\
\text { knowledge } \\
\text { management }\end{array}$ & $\begin{array}{l}\text { Traditionally, as in Stage I, top management had not paid great attention to the } \\
\text { IT function nor the KM function because it they were overhead functions that } \\
\text { generated only costs. At Stage II, greater top management participation in infor- } \\
\text { mation technology planning for knowledge management begins when IT and KM } \\
\text { strategies come to be used to support business strategies. The understanding } \\
\text { that strategic IT planning for KM can also influence business strategy motivates } \\
\text { top management to participate more actively in IT for KM planning. Finally, in } \\
\text { Stage IV, when the IT and KM functions become critical for the survival of the } \\
\text { organization, top management and senior IT and KM executives jointly formu- } \\
\text { late business and IT for KM plans. This benchmark variable was adapted based } \\
\text { on King and Teo's (1997) benchmark variable } 6 \text { concerned with top manage- } \\
\text { ment participation in information systems planning (ISP). They found a signifi- } \\
\text { cant del correlation between this benchmark variable and stages of integration. } \\
\text { They applied a scale from seldom to infrequent to frequent to almost always. } \\
\text { The group of judges in this research found the word "infrequent" difficult to un- } \\
\text { derstand. Hence, the revised scale is from rarely to sometimes to frequently to } \\
\text { almost always, as used by Guttman (1950, p. } 13 \text { and p. 19). }\end{array}$ \\
\hline 3 & $\begin{array}{l}\text { User man- } \\
\text { agement's } \\
\text { participation in } \\
\text { IT planning for } \\
\text { knowledge } \\
\text { management }\end{array}$ & $\begin{array}{l}\text { User participation in information technology planning for knowledge manage- } \\
\text { ment is the next benchmark variable. In the beginning, neither single users nor } \\
\text { user management are significantly involved in IT planning for KM. However, as } \\
\text { the IT and KM functions begin to influence functional units in terms of their ef- } \\
\text { fects on business performance, participation of users becomes more important } \\
\text { in order to fully exploit the potential of information technology. User participation } \\
\text { gradually increases through the stages, until at Stage IV, users participate ex- } \\
\text { tensively in IT planning for KM. This benchmark variable was adapted based on } \\
\text { King and Teo's (1997) benchmark variable } 7 \text { concerned with user participation in } \\
\text { information systems planning (ISP). However, they found only a weak del corre- } \\
\text { lation between this benchmark variable and stages of integration. They explain }\end{array}$ \\
\hline
\end{tabular}




\begin{tabular}{|c|c|c|}
\hline & & $\begin{array}{l}\text { this by arguing that users are more likely to be involved at the project level } \\
\text { rather than at the planning level. Therefore, user management, rather than us- } \\
\text { ers, was introduced in the construct in this research. }\end{array}$ \\
\hline 4 & $\begin{array}{l}\text { Principal con- } \\
\text { tribution from } \\
\text { IT for knowl- } \\
\text { edge man- } \\
\text { agement }\end{array}$ & $\begin{array}{l}\text { In the beginning, improved efficiency of individual lawyer's work in law firms was } \\
\text { the principal contribution from information technology for knowledge manage- } \\
\text { ment in law firms. Lawyers got access to electronic mail and word processors. } \\
\text { They were able to do the things right. At Stage II, lawyers did the right things by } \\
\text { improving their effectiveness. At Stage III, focus shifted from individual effective- } \\
\text { ness to organizational effectiveness. Ultimately, IT for KM improves the competi- } \\
\text { tiveness of the firm. This benchmark variable was adapted based on empirical } \\
\text { studies of law firms conducted by Gottschalk (2002). }\end{array}$ \\
\hline 5 & $\begin{array}{l}\text { Assessment } \\
\text { of knowledge } \\
\text { management } \\
\text { technology }\end{array}$ & $\begin{array}{l}\text { During information technology planning for knowledge management, new tech- } \\
\text { nologies, which can impact the firm, are usually assessed. The level of sophisti- } \\
\text { cation involved in assessing new technologies is the basis for this benchmark } \\
\text { variable. In the early stages (Stages I and II), assessment of the impact of new } \\
\text { technologies, if any, is usually done rather informally and infrequently. At Stage } \\
\text { III, the need for formal and frequent procedures for assessing new technologies } \\
\text { becomes apparent as IT and KM functions begin to play a more important role in } \\
\text { business planning. At Stage IV, assessment of the impact of new technologies } \\
\text { becomes an integral part of business, IT and KM planning. This benchmark } \\
\text { variable was adapted based on King and Teo's (1997) benchmark variable } 9 \\
\text { concerned with assessment of new technologies. However, they found only a } \\
\text { weak del correlation between this benchmark variable and stages of integration. } \\
\text { One possible reason is that in this era of rapid technological change, the as- } \\
\text { sessment of new technologies has become an integral part of planning regard- } \\
\text { less of the stage of integration. }\end{array}$ \\
\hline 6 & $\begin{array}{l}\text { Focus when } \\
\text { applying IT to } \\
\text { knowledge } \\
\text { management }\end{array}$ & $\begin{array}{l}\text { In the beginning, applications of information technology to support knowledge } \\
\text { management are focused on making IT available to lawyers (Stage I). When IT } \\
\text { tools are available to lawyers, then work processes are improved to enable } \\
\text { knowledge sharing among lawyers (Stage II). At Stage III, it is required to create } \\
\text { a culture for knowledge development, while replacement of lawyers by informa- } \\
\text { tion technology such as artificial intelligence (AI) is the focus at Stage IV. This } \\
\text { benchmark variable was adapted based on empirical studies of law firms con- } \\
\text { ducted by Gottschalk (2002). }\end{array}$ \\
\hline 7 & $\begin{array}{l}\text { Dominating } \\
\text { statement } \\
\text { about knowl- } \\
\text { edge man- } \\
\text { agement } \\
\text { technology }\end{array}$ & $\begin{array}{l}\text { In the beginning, PCs and networks enable lawyers to work on their own docu- } \\
\text { ments and notes and distribute the results to colleagues and to clients (Stage I). } \\
\text { Later, information is readily available from intranets and other sources to enable } \\
\text { lawyers to produce comprehensive documentation for clients using application } \\
\text { packages (Stage II). At Stage III, lawyers get access to expert opinions such as } \\
\text { successful cases, enabling them to make better legal advice decisions for their } \\
\text { clients. Ultimately, information technology enables lawyers to automate their } \\
\text { professional legal work at Stage IV. This benchmark variable was adapted } \\
\text { based on empirical studies of law firms conducted by Gottschalk (2002). }\end{array}$ \\
\hline 8 & $\begin{array}{l}\text { Main philoso- } \\
\text { phy for knowl- } \\
\text { edge man- } \\
\text { agement } \\
\text { technology }\end{array}$ & $\begin{array}{l}\text { For many years, lawyers have been able to focus on the role of client satisfac- } \\
\text { tion in knowledge management, where client trust and confidence in profes- } \\
\text { sional knowledge becomes important. When knowledge management has been } \\
\text { accepted as an important approach, then firm philosophy shifts to Stage II where } \\
\text { the firm is considered a knowledge community of people with a common inter- } \\
\text { est, problem and experience, designed and maintained for a business purpose. } \\
\text { To get started on information technology for knowledge management, it has to } \\
\text { have an appeal to knowledge workers. One important appeal is enjoying inde- } \\
\text { pendence in time and space, by working when they like (day or night) and where } \\
\text { they like (office, home, summerhouse). Finally at Stage IV, technology is helping }\end{array}$ \\
\hline
\end{tabular}




\begin{tabular}{|c|c|c|}
\hline & & $\begin{array}{l}\text { the client, rather than the lawyer, solve knowledge problems. This benchmark } \\
\text { variable was inspired by the legal grid developed by Susskind (2000). Also, } \\
\text { Grover and Davenport (2001) suggest a change in philosophy over time. They } \\
\text { argue that in the first of two phases, emphasis was on the knowledge manage- } \\
\text { ment project. What firms must do in the second phase of knowledge manage- } \\
\text { ment is to integrate it with familiar aspects of the business: strategy, human re- } \\
\text { source management, and managing expert knowledge. }\end{array}$ \\
\hline 9 & $\begin{array}{l}\text { Critical suc- } \\
\text { cess factor for } \\
\text { IT in knowl- } \\
\text { edge man- } \\
\text { agement }\end{array}$ & $\begin{array}{l}\text { Availability of PCs and networks is the basic requirement to enable access to } \\
\text { computing power and communication channels. At Stage II, availability of } \\
\text { knowledge management systems is important. The success of knowledge man- } \\
\text { agement systems is dependent on the quality and quantity of available informa- } \\
\text { tion in databases (Stage III). Such success is in turn dependent on both an or- } \\
\text { ganizational culture that has to be inspired and personal incentives that have to } \\
\text { be installed to create an active environment of knowledge sharing. This bench- } \\
\text { mark variable was adapted based on empirical studies of law firms conducted } \\
\text { by Gottschalk (2002). }\end{array}$ \\
\hline 10 & $\begin{array}{l}\text { Dominating } \\
\text { strategy for } \\
\text { knowledge } \\
\text { management } \\
\text { technology }\end{array}$ & $\begin{array}{l}\text { In the beginning, the tool strategy enables lawyers to use personal computers. } \\
\text { At Stage II, the stock strategy enables the firm to collect and store important in- } \\
\text { formation related to lawyers' work. At Stage III, further applications of knowledge } \\
\text { management technology are according to the flow strategy where information } \\
\text { storing is limited to documents that will be used again in work processes. The } \\
\text { growth strategy of only storing documents that are related to legal work where } \\
\text { the firm is inexperienced, but interested, occurs at Stage IV. This benchmark } \\
\text { variable was inspired by alternative knowledge strategies as defined by Hansen } \\
\text { (1999). }\end{array}$ \\
\hline 11 & $\begin{array}{l}\text { Main task of } \\
\text { information } \\
\text { technology in } \\
\text { knowledge } \\
\text { management }\end{array}$ & $\begin{array}{l}\text { Creating notes and documents on an individual basis is often the first computer } \\
\text { task performed by a knowledge worker. The result of each task is distributed to a } \\
\text { secretary, a colleague and/or a client. At Stage II, information technology's main } \\
\text { task is to be active in capturing information that is the result of knowledge work } \\
\text { in the firm. Later, at Stage III, knowledge sharing and exchange occurs when the } \\
\text { knowledge worker both distributes and receives electronic information. Ulti- } \\
\text { mately, IT is introduced to solve client problems by applying knowledge that has } \\
\text { been codified in information databases. This benchmark variable was inspired } \\
\text { by empirical research conducted by Gottschalk (2002). }\end{array}$ \\
\hline 12 & $\begin{array}{l}\text { Main purpose } \\
\text { of IT in knowl- } \\
\text { edge man- } \\
\text { agement }\end{array}$ & $\begin{array}{l}\text { Administrative work processes had to be simplified to cut rising administration } \\
\text { costs in law firms. At Stage II, the main purpose of IT in knowledge management } \\
\text { shifted to providing access to information more efficiently. At Stage III, doing } \\
\text { things right is replaced by doing the right things. Finally, the main purpose is to } \\
\text { automate legal work done by lawyers. This benchmark variable was inspired by } \\
\text { empirical research conducted by Gottschalk (2002). }\end{array}$ \\
\hline 13 & $\begin{array}{l}\text { Main applica- } \\
\text { tions of IT }\end{array}$ & $\begin{array}{l}\text { Based on Susskind's (2000) legal grid, this benchmark variable suggests that } \\
\text { there is a progression from office support, via customer relationships and } \\
\text { knowledge management, to legal web advice. This progression may vary among } \\
\text { firms, thereby making such a standard progression questionable. Nevertheless, } \\
\text { this benchmark variable was included to enable empirical measurement of the } \\
\text { legal grid. }\end{array}$ \\
\hline 14 & $\begin{array}{l}\text { Attitude to- } \\
\text { wards IT in } \\
\text { knowledge } \\
\text { management }\end{array}$ & $\begin{array}{l}\text { Based on Tiwana's ( } 2001, \text { p. } 157) \text { proposal that there are skeptics, conserva- } \\
\text { tives, early adopters and innovators, this classification was introduced as a } \\
\text { scale. }\end{array}$ \\
\hline 15 & Contribution to & Value shop is a value configuration consisting of five primary activities as de- \\
\hline
\end{tabular}




\begin{tabular}{|c|c|c|}
\hline & $\begin{array}{l}\text { primary activi- } \\
\text { ties in the } \\
\text { value shop }\end{array}$ & $\begin{array}{l}\text { fined by Stabell and Fjeldstad (1997). It has been suggested that the role of in- } \\
\text { formation systems varies across primary activities. While end-user-tools are im- } \\
\text { portant for understanding clients' problems, what-they-know systems are impor- } \\
\text { tant for solving clients' problems, how-they-think systems are important for se- } \\
\text { lecting an optimal solution to clients' problems, while who-knows-what systems } \\
\text { are important for implementing the optimal solution to clients' problems. }\end{array}$ \\
\hline 16 & $\begin{array}{l}\text { Contribution of } \\
\text { IT function }\end{array}$ & $\begin{array}{l}\text { The role of the IT function may be viewed differently at the various stages of } \\
\text { knowledge management technology. The general transition from being techni- } \\
\text { cally oriented to being business oriented is well documented in the literature. At } \\
\text { Stages I and II, the IT function is technically oriented as supplier of PCs and end } \\
\text { user tools and as developer of technical infrastructure and applications. At } \\
\text { Stages III and IV, the IT function is business oriented as a resource making in- } \\
\text { formation available and as a supplier of systems that automate legal work. This } \\
\text { benchmark variable was adapted based on King and Teo's (1997) benchmark } \\
\text { variable } 2 \text { concerned with the role of the IS function. They found a significant del } \\
\text { correlation between this benchmark variable and stages of integration. }\end{array}$ \\
\hline 17 & $\begin{array}{l}\text { Role of IT } \\
\text { manager }\end{array}$ & $\begin{array}{l}\text { The skill requirements of the senior IT executive have changed over the years } \\
\text { with increasing emphasis on both competence about changing technology and } \\
\text { competence about business applications. The role of the IT executive gradually } \\
\text { changes from being an information technology expert (Stage I) and a functional } \\
\text { administrator (Stage II), to being an information resources manager (Stage III) } \\
\text { who focuses on knowledge management systems (Stage IV). This benchmark } \\
\text { variable was adapted based on King and Teo's (1997) benchmark variable } 3 \\
\text { concerned with the primary role of the IS executive. They found a significant del } \\
\text { correlation between this benchmark variable and stages of integration. This } \\
\text { benchmark variable was also inspired by Drazin and Kazanjian (1993) who iden- } \\
\text { tified backgrounds of CEOs depending on growth stage. }\end{array}$ \\
\hline 18 & $\begin{array}{l}\text { Performance } \\
\text { of IT function }\end{array}$ & $\begin{array}{l}\text { As the IT function matures, the performance criteria for the IT function change } \\
\text { from structured focus on operational efficiency to a more unstructured concern } \\
\text { for contribution to business strategy in general and knowledge strategy in par- } \\
\text { ticular. It follows that the early performance criteria (Stage I) delineated for the IT } \\
\text { function are primarily concerned with operational efficiency and cost minimiza- } \\
\text { tion. When the IT function begins to play a more strategic role, the emphasis } \\
\text { gradually shifts to effective strategy implementation (Stages II and III). Ulti- } \\
\text { mately, the performance criteria for the IT function should be its long-term im- } \\
\text { pact (both financial and non-financial) on the competitive position of the organi- } \\
\text { zation (Stage 4). This benchmark variable was adapted based on King and Teo's } \\
\text { (1997) benchmark variable } 4 \text { concerned with performance criteria for the IT } \\
\text { function. However, they found only a weak del correlation between this bench- } \\
\text { mark variable and stages of integration. This may be due to the multidimen- } \\
\text { sional nature of performance. For instance, top management may be vague as } \\
\text { to the relative importance of each performance criterion. }\end{array}$ \\
\hline 19 & $\begin{array}{l}\text { Key issue for } \\
\text { IT function }\end{array}$ & $\begin{array}{l}\text { Over time, business organizations have developed and advanced in their use of } \\
\text { IT. In the beginning, there was data processing and data processing systems. } \\
\text { Then there were management information systems and strategic information } \\
\text { systems. Finally, in the network era, there is communication and interaction. } \\
\text { This benchmark variable was based on Nolan's (1979) model focusing on the } \\
\text { level of IS expenditures. }\end{array}$ \\
\hline 20 & $\begin{array}{l}\text { IT manager's } \\
\text { participation }\end{array}$ & $\begin{array}{l}\text { This benchmark variable is concerned with IT executive participation in business } \\
\text { planning. The mirror image of top business management participation in IT } \\
\text { planning for KM is IT executives participate in business planning. The traditional } \\
\text { role of the IT function in providing administrative support does not require the } \\
\text { senior IT executive to participate in business planning (Stage I). The senior IT }\end{array}$ \\
\hline
\end{tabular}




\begin{tabular}{|c|c|c|}
\hline & & $\begin{array}{l}\text { executive reacts to business plans and does not have significant influence on } \\
\text { their formulation. At Stage II, the senior IT executive participation is initiated, } \\
\text { growing to almost always participation at Stage IV. This benchmark variable was } \\
\text { adapted based on King and Teo's (1997) benchmark variable } 8 \text { concerned with } \\
\text { IS executive participation in business planning. They found a significant del cor- } \\
\text { relation between this benchmark variable and stages of integration. They ap- } \\
\text { plied a scale from seldom to infrequent to frequent to almost always. The group } \\
\text { of judges in this research found the word "infrequent" difficult to understand. } \\
\text { Hence, the revised scale is from rarely to sometimes to frequently to almost al- } \\
\text { ways, as used by Guttman (1950, p. } 13 \text { and p. 19). }\end{array}$ \\
\hline 21 & $\begin{array}{l}\text { Status of IT } \\
\text { executive }\end{array}$ & $\begin{array}{l}\text { The responsibilities of the IT function have changed over the years due to tech- } \\
\text { nological and conceptual changes that made information technology more im- } \\
\text { portant to organizations. With these changing responsibilities of the IT function, } \\
\text { the status of the senior IT executive is likely to be elevated. The position of the } \\
\text { senior IT executive (in terms of the number of levels below the CEO) can serve } \\
\text { as an indication of the importance of the IT function to the firm's strategy. This } \\
\text { benchmark variable was adapted based on King and Teo's (1997) benchmark } \\
\text { variable } 10 \text { concerned with the status of senior IS executive. They found a sig- } \\
\text { nificant del correlation between this benchmark variable and stages of integra- } \\
\text { tion. }\end{array}$ \\
\hline 22 & $\begin{array}{l}\text { Level of busi- } \\
\text { ness knowl- } \\
\text { edge }\end{array}$ & $\begin{array}{l}\text { Knowledge focus will be different in expert-driven, experience-driven and effi- } \\
\text { ciency-driven businesses. In the expert-driven business, learning is important, } \\
\text { while previous knowledge becomes obsolete. In the experience-driven business, } \\
\text { know-how concerning problem solutions is important, while knowledge of previ- } \\
\text { ous problems becomes obsolete. In the efficiency-based business, all knowl- } \\
\text { edge concerning both problems and solutions is important in an accumulation of } \\
\text { knowledge to improve efficiency. These differences lead Hansen (1999) to make } \\
\text { distinctions between the following three knowledge management strategies of } \\
\text { stock strategy, flow strategy and growth strategy as measured in another } \\
\text { benchmark variable. }\end{array}$ \\
\hline 23 & $\begin{array}{l}\text { Main effect of } \\
\text { knowledge } \\
\text { management }\end{array}$ & $\begin{array}{l}\text { In the beginning, a law firm wants to reduce its dependence on individual law- } \\
\text { yer's knowledge. As the CEO of a large law firm in Norway said: "I would like } \\
\text { some of the knowledge to stay in the firm when all lawyers leave at night". At } \\
\text { Stage II, the main effect is effective application of current knowledge in the firm. } \\
\text { Development of new knowledge becomes the most important effect at Stage III, } \\
\text { while external orientation towards client performance is at the firms' attention at } \\
\text { Stage IV. This benchmark variable was inspired by empirical research con- } \\
\text { ducted by Gottschalk (2002). }\end{array}$ \\
\hline 24 & $\begin{array}{l}\text { Knowledge } \\
\text { management } \\
\text { priority in } \\
\text { business } \\
\text { strategy }\end{array}$ & $\begin{array}{l}\text { Law firms in Norway became aware of the resource-based theory of the firm } \\
\text { with the knowledge-based perspective in the late 1990s. A partner was asked to } \\
\text { investigate the matter, but knowledge management had low priority in the busi- } \\
\text { ness strategy. After some years, the priority of knowledge management in busi- } \\
\text { ness strategy rose. At Stage IV, knowledge management has the first priority in } \\
\text { business strategy. This benchmark variable was inspired by empirical research } \\
\text { conducted by Gottschalk (2002). }\end{array}$ \\
\hline 25 & $\begin{array}{l}\text { Management } \\
\text { agenda }\end{array}$ & $\begin{array}{l}\text { In the beginning, knowledge management was at the top management agenda } \\
\text { only once a year (Stage I). Later, knowledge management was on the agenda } \\
\text { every month (Stage II) and every week (Stage III). At Stage IV, knowledge man- } \\
\text { agement is a daily task of top management. This benchmark variable was in- } \\
\text { spired by empirical research conducted by Gottschalk (2002). }\end{array}$ \\
\hline 26 & $\begin{array}{l}\text { Knowledge } \\
\text { management }\end{array}$ & $\begin{array}{l}\text { Law firms in Norway became aware of the resource-based theory of the firm } \\
\text { with the knowledge-based perspective in the late 1990s. A partner was asked to }\end{array}$ \\
\hline
\end{tabular}




\begin{tabular}{|c|c|c|}
\hline & $\begin{array}{l}\text { priority in } \\
\text { marketing } \\
\text { strategy }\end{array}$ & $\begin{array}{l}\text { investigate the matter, but knowledge management had low priority in the mar- } \\
\text { keting strategy as knowledge management was considered an internal issue. } \\
\text { After some years, the priority of knowledge management in marketing strategy } \\
\text { grew. Firm executives perceived that internal knowledge management was } \\
\text { tightly linked to client service, as suggested by the legal grid by Susskind } \\
\text { (2000). At Stage IV, knowledge management has the first priority in marketing } \\
\text { strategy. }\end{array}$ \\
\hline 27 & $\begin{array}{l}\text { Description of } \\
\text { normal work }\end{array}$ & $\begin{array}{l}\text { Traditionally, law firms provide clients with a comfortable and user-friendly ex- } \\
\text { perience using established procedures to tackle familiar types of problem. } \\
\text { Knowledge focus will be different depending on typical work done in the firm. At } \\
\text { Stage II we find a low cost, efficiently organized delivery team using established } \\
\text { methods for routine assignments. Firms at Stage III provide clients with creative, } \\
\text { innovative solutions to one-off problems, while firms at Stage IV work continu- } \\
\text { ously with clients on real-time diagnosis of complex, ill-specified problems. This } \\
\text { contingent approach to knowledge management was inspired by Hansen (1999) } \\
\text { who distinguished between efficiency-based, experience-based and expert- } \\
\text { based firms as measured in another benchmark variable. }\end{array}$ \\
\hline 28 & $\begin{array}{l}\text { Knowledge } \\
\text { growth }\end{array}$ & $\begin{array}{l}\text { Tiwana (2001, p. 279) argues that the stages of knowledge growth framework } \\
\text { provides a readily usable methodology for measurement of process capability } \\
\text { and technological knowledge. According to the framework, a business pro- } \\
\text { gresses from stage } 1 \text {, ignorance, via awareness, measure, control of the mean, } \\
\text { process capability, process characterization, know why to stage } 8 \text {, perfect } \\
\text { knowledge. These stages were in this research transformed to know-what, } \\
\text { know-why, know-how-we, and know-how-clients. }\end{array}$ \\
\hline 29 & $\begin{array}{l}\text { Knowledge } \\
\text { characteristics }\end{array}$ & $\begin{array}{l}\text { Tiwana }(2001, \text { p. } 279) \text { argues that the stages of knowledge characteristics pro- } \\
\text { vides a frame of reference against which a business can map, evaluate, and } \\
\text { measure business relative to competitors and industry. According to the frame- } \\
\text { work, a business progresses from stage } 0 \text {, undefined, via pure art, list of possi- } \\
\text { bly relevant variables, pre-technological, scientific method, local repeatable rec- } \\
\text { ipe, cost effective handling, quantitative model, to stage } 8 \text {, Nirvana. }\end{array}$ \\
\hline 30 & $\begin{array}{l}\text { Status of KM } \\
\text { executive }\end{array}$ & $\begin{array}{l}\text { The responsibilities of the knowledge management function have changed over } \\
\text { the years due to conceptual changes that made knowledge management more } \\
\text { important to organizations. With these changing responsibilities of the KM func- } \\
\text { tion, the status of the senior KM executive is likely to be elevated. The position } \\
\text { of the senior KM executive (in terms of the number of levels below the CEO) can } \\
\text { serve as an indication of the importance of the KM function to the firm's strategy. } \\
\text { This benchmark variable was adapted based on King and Teo's (1997) bench- } \\
\text { mark variable } 10 \text { concerned with the status of senior IS executive. They found a } \\
\text { significant del correlation between this benchmark variable and stages of inte- } \\
\text { gration. }\end{array}$ \\
\hline 31 & $\begin{array}{l}\text { Response } \\
\text { time to clients' } \\
\text { enquiries }\end{array}$ & $\begin{array}{l}\text { Voss (2000) suggests that a metric for customer relationship management } \\
\text { should be the response time to customers' enquiries (e.g., } 24 \text {-hour limit). He } \\
\text { measured } 70 \text { UK companies' responsiveness to enquiries. He found that } 47 \% \\
\text { responded within one day, } 16 \% \text { responded within a week, and } 37 \% \text { did not re- } \\
\text { spond at all.This idea is implemented as a benchmark variable here to illustrate } \\
\text { that response time will decline when information technology is used in knowl- } \\
\text { edge management in the law firm. }\end{array}$ \\
\hline 32 & $\begin{array}{l}\text { Response } \\
\text { quality }\end{array}$ & $\begin{array}{l}\text { Voss (2000) suggests that a metric for customer relationship management } \\
\text { should be response quality, for example making customers' happy with the re- } \\
\text { sponses } 95 \% \text { of the time. This idea is implemented as a benchmark variable } \\
\text { here to illustrate that response quality will improve when information technology } \\
\text { is used in knowledge management in the law firm. }\end{array}$ \\
\hline
\end{tabular}




\section{Appendix C: Knowledge Management Technology Survey}

What is your job title?

How many years have you been with the firm? years

How many persons work in the firm? persons

How many lawyers work in the firm? persons

How many persons are partners in the firm? persons

What is the total income budget for the firm this year? mill. NOK

What is the total IT budget for the firm this year? mill. NOK

How many persons work in the IT function in the firm? persons

\begin{tabular}{|c|c|c|c|c|}
\hline $\begin{array}{c}\text { END-USER-TOOL SYSTEMS } \\
\text { To what extent is the following information tech- } \\
\text { nology used by lawyers in the firm: }\end{array}$ & $\begin{array}{l}\text { To a little } \\
\text { extent }\end{array}$ & & & $\begin{array}{l}\text { To a great } \\
\text { extent }\end{array}$ \\
\hline Text processing (e.g., Word) & 2 & 3 & 4 & 6 \\
\hline Presentations (e.g., PowerPoint) & 12 & 3 & 4 & 5 \\
\hline Electronic mail (e.g., Notes mail) & 1 & 3 & 4 & 6 \\
\hline External legal databases (e.g., Lovdata) & 2 & 3 & 4 & 5 \\
\hline End user tools for lawyers & 12 & 3 & 4 & 5 \\
\hline $\begin{array}{l}\text { WHO-KNOWS-WHAT SYSTEMS } \\
\text { To what extent is the following information tech- } \\
\text { nology used by lawyers in the firm: }\end{array}$ & \multicolumn{3}{|l|}{$\begin{array}{l}\text { To a little } \\
\text { extent }\end{array}$} & $\begin{array}{r}\text { To a great } \\
\text { extent }\end{array}$ \\
\hline Groupware for cooperation (e.g., GroupWise, Lotus Notes) & 2 & 3 & 4 & 5 \\
\hline The firm's intranet & 2 & 3 & 4 & 5 \\
\hline The firm's own web pages on the Internet & 2 & 3 & 4 & 5 \\
\hline Internal standards database & 2 & 3 & 4 & 5 \\
\hline Systems providing information about lawyers' knowlec & 1 & 3 & 4 & 5 \\
\hline
\end{tabular}

\begin{tabular}{|l|llllll|}
\hline $\begin{array}{c}\text { WHAT-THEY-KNOW SYSTEMS } \\
\begin{array}{c}\text { To what extent is the following information tech- } \\
\text { nology used by lawyers in the firm: }\end{array}\end{array}$ & $\begin{array}{l}\text { To a little } \\
\text { extent }\end{array}$ & & & $\begin{array}{c}\text { To a great } \\
\text { extent }\end{array}$ \\
\hline Groupware for knowledge (e.g., GroupWise, Lotus Notes) & 1 & 2 & 3 & 4 & 5 & 6 \\
\hline Database with client cases & 1 & 2 & 3 & 4 & 5 & 6 \\
\hline Database with best practices & 1 & 2 & 3 & 4 & 5 & 6 \\
\hline Document system (e.g., DocsOpen) & 1 & 2 & 3 & 4 & 5 & 6 \\
\hline Systems providing information based on lawyers' knowledge & 1 & 2 & 3 & 4 & 5 & 6 \\
\hline
\end{tabular}




\begin{tabular}{|l|llllll|}
\hline $\begin{array}{c}\text { HOW-THEY-THINK SYSTEMS } \\
\begin{array}{c}\text { To what extent is the following information tech- } \\
\text { nology used by lawyers in the firm: }\end{array}\end{array}$ & $\begin{array}{l}\text { To a little } \\
\text { extent }\end{array}$ & & & $\begin{array}{c}\text { To a great } \\
\text { extent }\end{array}$ \\
\hline Expert system (e.g., Knowledger) & 1 & 2 & 3 & 4 & 5 & 6 \\
\hline Neural network system & 1 & 2 & 3 & 4 & 5 & 6 \\
\hline Intelligent agent (e.g., Autonomy) & 1 & 2 & 3 & 4 & 5 & 6 \\
\hline Case-based reasoning system & 1 & 2 & 3 & 4 & 5 & 6 \\
\hline Systems solving knowledge problems for lawyers & 1 & 2 & 3 & 4 & 5 & 6 \\
\hline
\end{tabular}

\section{Please indicate the approximate number of years:}

The information technology manager position has been in the firm for years.

The knowledge manager position has been in the firm for years.

Lawyers in the firm have access to Lovdata for years.

Knowledge management has been a management topic in the firm for years

For each of the following statements, please place one check mark ( 1 besides the description that most closely fits the firm. Please choose only one response for each numbered statement. (Even though more than one response may seem appropriate, please select the best statement for the firm). Please also note that none of the descriptions are inherently good or bad.

1. The implementation of information technology for knowledge management is primarily triggered by:

$>$ ( ) consideration of individual lawyers' needs for IT tools

$>$ ( ) consideration of the organization's needs for information

$>$ ( ) the need to develop the firm by automating lawyers' information work

$>(\mathrm{l})$ the need to transform the firm by automating lawyers' knowledge work

2. Please indicate the frequency of top management's participation in strategic information technology planning for knowledge management:

$>$ ( ) rarely

$>$ ( ) sometimes

$>$ ( ) frequently

$>$ ( ) almost always

3. Please indicate the frequency of user management's participation in strategic information technology planning for knowledge management:
$>$ ( ) rarely
$>$ ( ) sometimes
$>$ ( ) frequently
$>$ ( ) almost always

4. The principal contribution from information technology in knowledge management is:

$>$ ( ) improved efficiency of individual lawyer's work (efficiency = do the things right)

$>$ ( ) improved effectiveness of individual lawyer's work (effectiveness $=$ do the right things)

$>$ ( ) improved effectiveness of the firm

$>$ ( ) improved competitiveness of the firm 
5. During information technology planning, how frequent is the impact of new knowledge management technologies assessed?
$>$ ( ) rarely
$>$ ( ) sometimes
$>$ ( ) frequently
$>$ ( ) almost always

6. In applying information technology to support knowledge management, we have the following main focus:

$>$ ( ) making information technology available to lawyers

$>$ ( ) reorganizing the firm for knowledge sharing

$>$ ( ) creating a culture for knowledge development

$>$ ( ) replacing lawyers' legal work by artificial intelligence (Al) systems

7. Please indicate the most dominating statement about knowledge management technology among lawyers:

$>$ ( ) information technology enables me to distribute information to my colleagues

$>$ ( ) information technology enables me to produce comprehensive documentation for clients

$>$ ( ) information technology enables me to make better legal advice decisions

$>$ ( ) information technology enables me to automate my professional legal work

8. Please indicate the main 'philosophy' for knowledge management technology:

$>$ ( ) our clients are satisfied with our work, they have trust and confidence in our professional knowledge

$>$ ( ) our firm is a knowledge community of people with a common interest, problem and experience, designed and maintained for a business purpose

$>\quad$ ( ) our lawyers enjoy independence in time and space, by working when they like (day or night) and where they like (office, home, summerhouse)

$>$ ( ) we help our clients solve their problems themselves by making expert knowledge available

9. The most critical success factor for information technology in knowledge management is:

$>$ ( ) availability of PCs and networks

$>\quad$ ( ) availability of knowledge management systems

$>$ ( ) quality and quantity of available information in databases

$>($ ) culture and incentives to share knowledge

10. Please indicate the dominating strategy for knowledge management technology:

$>$ ( ) tool strategy of enabling lawyers to use PCs

$>$ ( ) stock strategy of storing whatever documents that are produced in the firm

$>$ ( ) flow strategy of only storing documents that will be used again in work processes

$>$ ( ) growth strategy of only storing documents that are related to important legal work where we have little experience

11. Presently, the main task of information technology in knowledge management is:

$>$ ( ) distributing knowledge

$>$ ( ) capturing knowledge

$>$ ( ) sharing knowledge

$>$ ( ) applying knowledge 
12. Presently, information technology in knowledge management mainly exists for the purpose of:

$>$ ( ) facilitating administrative work processes

$>$ ( ) providing access to information more efficiently

$>$ ( ) sharing information more effectively

$>$ ( ) automating professional legal work done by lawyers

13. Presently, the main applications of information technology consist of:

$>$ ( ) office support systems

$>$ ( ) customer relationship management systems

$>$ ( ) knowledge management systems

$>$ ( ) online legal web advice systems

14. Please indicate the firm's attitude towards information technology for knowledge management:

$>$ ( ) we are skeptics

$>\quad($ ) we are conservatives

$>$ ( ) we are early adopters

$>$ ( ) we are innovators

15. Please indicate the most dominating application area for information technology:

$>$ ( ) Understanding clients' problems

$>$ ( ) Implementing solutions to clients' problems

$>$ ( ) Solving clients' problems

$>$ ( ) Selecting optimal solutions to clients' problems

16. The information technology function is primarily viewed as:

$>$ ( ) supplier of PCs and end user tools

$>$ ( ) developer of technical infrastructure and applications

$>$ ( ) a resource making information available

$>$ ( ) supplier of systems that automate professional legal work

17. The primary role of the information technology manager is:

$>$ ( ) an information technology expert who knows PCs and IT tools

$>$ ( ) a functional administrator responsible for providing support

$>$ ( ) an information resources manager

$>$ ( ) a knowledge management systems expert

18. The performance criteria for the information technology function are its:

$>$ ( ) operational efficiency and cost minimization

$>$ ( ) contribution to business strategy implementation

$>\quad($ ) contribution to knowledge strategy implementation

$>$ ( ) long-term impact on the competitive position of the firm

19. Please indicate a key issue for the IT function:

$>\quad($ ) effective personal computers

$>$ ( ) effective data processing

$>\quad($ ) effective information systems

$>($ ) effective information networks 
20. Please indicate the frequency of the information technology manager's participation in business strategy planning:
$>$ ( ) rarely
$>$ ( ) sometimes
$>$ ( ) frequently
$>$ ( ) almost always

21. Please indicate the number of levels the information technology manager is below the chief executive officer (CEO):

$>$ ( ) three or more

$>$ ( ) two

$>$ ( ) one, reporting to the CEO

$>$ ( ) one, reporting to the CEO and with direct access to the board

22. We are in the business of providing legal advice:
$>$ ( ) based on availability of our lawyers
$>$ ( ) based on efficiency of our lawyers
$>$ ( ) based on effectiveness of our lawyers
$>$ ( ) based on expert knowledge of our lawyers

23. Knowledge management has the following main effect:
$>$ ( ) reduced dependence on individual lawyer's knowledge
$>$ ( ) effective application of current knowledge
$>$ ( ) effective development of new knowledge
$>($ ) improved client performance

24. Knowledge management has the following priority in our business strategy:
$>$ ( ) fourth priority
$>($ ) third priority
$>$ ( ) second priority
$>$ ( ) first priority

25. Knowledge management is at the top management agenda:
$>$ ( ) every year
$>$ ( ) every month
$>$ ( ) every week
$>($ ) every day

26. Knowledge management has the following priority in our marketing strategy:

$>$ ( ) fourth priority

$>$ ( ) third priority

$>$ ( ) second priority

$>$ ( ) first priority

27. Which of the following best describes the work normally done:

$>$ ( ) providing clients with a comfortable and user-friendly experience using established procedures to tackle familiar types of problem

$>\quad$ ( ) a low cost, efficiently organized delivery team using established methods for routine assignments

$>$ ( ) providing clients with creative, innovative solutions to one-off problems

$>$ ( ) working continuously with clients on real-time diagnosis of complex, ill-specified problems 
28. Please indicate the stage of knowledge growth:

$>$ ( ) know-what client problems occur

$>$ ( ) know-why client problems occur

$>$ ( ) know-how client problems can be solved

$>$ ( ) know-how clients can solve their problems

29. Please indicate the stage of knowledge characteristics:

$>$ ( ) experts dictate process execution that is subject to randomness

$>$ ( ) some knowledge is explicated and codified

$>$ ( ) knowledge is documented in a methodology that usually works

$>$ ( ) relevant knowledge is well explicated and codified; contingencies can be handled well

30. Please indicate the number of levels the knowledge manager is below the chief executive officer (CEO):

$>$ ( ) three or more

$>$ ( ) two

$>$ ( ) one, reporting to the CEO

$>$ ( ) one, reporting to the CEO and with direct access to the board

31. Please indicate the average response time to clients' enquiries:
$>$ ( ) one week
$>$ ( ) one day
$>$ ( ) one hour
$>($ ) one minute

32. Please indicate the response quality, where quality is defined as making clients happy with the responses some percent of the time:

$>$ ( ) our clients are happy with our responses less than $50 \%$ of the time

$>$ ( ) our clients are happy with our responses between $50 \%$ and $89 \%$ of the time

$>$ ( ) our clients are happy with our responses $90 \%$ to $95 \%$ of the time

$>$ ( ) our clients are happy with our responses more than $95 \%$ of the time

Please indicate with one check mark $(\sqrt{ })$ the description that most closely fits your current projects for information technology to support knowledge management in the firm:

$>$ ( ) End-user tools will be made available to lawyers. This means a capable networked PC on every desk or in every briefcase, with standardized personal productivity tools (word processing, presentation software) so that documents can be exchanged easily throughout a company. A widespread dissemination and use of end-user tools among knowledge workers in the company is to take place.

$>$ ( ) Information about who knows what will be made available to lawyers. It aims to record and disclose who in the organization knows what by building knowledge directories. Often called 'yellow pages', the principal idea is to make sure knowledgeable people in the organization are accessible to others for advice, consultation, or knowledge exchange. Knowledge-oriented directories are not so much repositories of knowledge-based information as gateways to knowledge.

$>$ ( ) Information from lawyers will be stored and made available to colleagues. Here data mining techniques will be applied to find relevant information and combine information in data warehouses. One approach is to store project reports, notes, recommendations and letters from each lawyers in the firm. Over time, this material will grow fast, making it necessary for a librarian or a chief knowledge officer (CKO) to organize it. 
> ( ) Information systems solving knowledge problems will be made available to lawyers. Artificial intelligence will be applied in these systems. For example, neural networks are statistically oriented tools that excel at using data to classify cases into one category or another. Another example is expert systems that can enable the knowledge of one or a few experts to be used by a much broader group of lawyers who need the knowledge.

As far back as you can recall, please indicate below the evolution of information technology projects for knowledge management in the firm in terms of the duration spent in each type of information technology projects, and the reasons for changing from the previous type of knowledge management technologies. Please use the terms 'not applicable' or 'NA' beside any type of information technology projects that the firm did not experience.

\begin{tabular}{|l|l|l|}
\hline $\begin{array}{l}\text { Information technology pro- } \\
\text { jects focused on: }\end{array}$ & $\begin{array}{l}\text { Duration (e.g., } \\
1997-1999)\end{array}$ & $\begin{array}{l}\text { Reasons for changing from the previous } \\
\text { project type to this type }\end{array}$ \\
\hline $\begin{array}{l}\text { Tools for lawyers, both } \\
\text { hardware and software } \\
\text { tools (end-user-tools IT pro- } \\
\text { jects) }\end{array}$ & & \\
\hline $\begin{array}{l}\text { Systems storing information } \\
\text { about which lawyers know } \\
\text { what (who-knows-what IT } \\
\text { projects) }\end{array}$ & & \\
\hline $\begin{array}{l}\text { Knowledge from lawyers } \\
\text { stored as information and } \\
\text { made available (what-they- } \\
\text { know IT projects) }\end{array}$ & & \\
\hline $\begin{array}{l}\text { Information systems solving } \\
\text { knowledge problems for } \\
\text { lawyers (how-they-think IT } \\
\text { projects) }\end{array}$ & & \\
\hline
\end{tabular}

\begin{tabular}{|l|llllll|}
\hline $\begin{array}{l}\text { KNOWLEDGE-SHARING PERCEPTIONS } \\
\begin{array}{l}\text { To what extent do you disagree or agree with the fol- } \\
\text { lowing statements about the firm: }\end{array}\end{array}$ & $\begin{array}{c}\text { Strongly } \\
\text { disagree }\end{array}$ & & $\begin{array}{c}\text { Strongly } \\
\text { agree }\end{array}$ \\
\hline $\begin{array}{l}\text { Lawyers are encouraged to share with others what they have } \\
\text { learned from their recent assignments }\end{array}$ & 1 & 2 & 3 & 4 & 5 \\
\hline $\begin{array}{l}\text { Senior staff are too busy to reflect on their experiences and share } \\
\text { them }\end{array}$ & 1 & 2 & 3 & 4 & 5 \\
\hline $\begin{array}{l}\text { The firm has a well-organised system for sharing knowledge (e.g. } \\
\text { about clients, managing projects, new approaches) within depart- } \\
\text { ments or practice areas }\end{array}$ & 1 & 2 & 3 & 4 & 5 \\
\hline $\begin{array}{l}\text { The firm has a well-organised system for sharing knowledge (e.g. } \\
\text { about clients, managing projects, new approaches) across depart- } \\
\text { ments or practice areas }\end{array}$ & 1 & 2 & 3 & 4 & 5 \\
\hline $\begin{array}{l}\text { There is an expectation that lawyers or their teams will have to take } \\
\text { a regular turn to provide a reflection on learning experiences }\end{array}$ & 1 & 2 & 3 & 4 & 5 \\
\hline Sharing knowledge systematically is part of the firm's culture & 1 & 2 & 3 & 4 & 5 \\
\hline
\end{tabular}




\begin{tabular}{|l|llllll|}
\hline $\begin{array}{l}\text { REWARD ATTITUDES } \\
\begin{array}{l}\text { To what extent do you disagree or agree with the fol- } \\
\text { lowing statements about the firm: }\end{array}\end{array}$ & $\begin{array}{l}\text { Strongly } \\
\text { disagree }\end{array}$ & & $\begin{array}{c}\text { Strongly } \\
\text { agree }\end{array}$ \\
\hline $\begin{array}{l}\text { Lawyer salary increases in the firm are based on ability and how } \\
\text { well he/she does his/her work }\end{array}$ & 1 & 2 & 3 & 4 & 5 \\
\hline $\begin{array}{l}\text { Promotion of a lawyer in the firm is based on ability and how well } \\
\text { he/she does his/her work }\end{array}$ & 1 & 2 & 3 & 4 & 5 \\
\hline Lawyers are fairly rewarded for the amount of effort they put in & 1 & 2 & 3 & 4 & 5 \\
\hline $\begin{array}{l}\text { The interest of the work lawyers do compensates for long hours } \\
\text { and a stressful workload }\end{array}$ & 1 & 2 & 3 & 4 & 5 \\
\hline The team as a whole is rewarded for good work & 1 & 2 & 3 & 4 & 5 \\
\hline Teamwork in this firm is fully recognized and rewarded & 1 & 2 & 3 & 4 & 5 \\
\hline
\end{tabular}

\begin{tabular}{|c|c|c|c|c|c|}
\hline $\begin{array}{l}\text { SUPPORT FOR PERSONAL DEVELOPMENT } \\
\text { To what extent do you disagree or agree with the fol- } \\
\text { lowing statements about the firm: }\end{array}$ & $\begin{array}{l}\text { Stron } \\
\text { disag }\end{array}$ & & & & $\begin{array}{l}\text { ongly } \\
\text { agree }\end{array}$ \\
\hline $\begin{array}{l}\text { The firm provide each lawyer with a well structured training and } \\
\text { development program }\end{array}$ & 1 & 2 & 3 & & 5 \\
\hline It allocates a generous amount of time for each lawyer's training & 1 & 2 & 3 & & 5 \\
\hline $\begin{array}{l}\text { Training time and opportunity is often squeezed by day to day work } \\
\text { pressures }\end{array}$ & 1 & & & & 5 \\
\hline $\begin{array}{l}\text { Lawyers are encouraged to learn both about the law and about } \\
\text { business practice and marketing }\end{array}$ & 1 & 2 & & & \\
\hline $\begin{array}{l}\text { Lawyers often do tasks without seeing where they fit into the wider } \\
\text { picture }\end{array}$ & 1 & 2 & 3 & & 5 \\
\hline $\begin{array}{l}\text { I believe lawyers could successfully undertake higher level tasks if } \\
\text { there was more effective delegation }\end{array}$ & 1 & 2 & 3 & & 5 \\
\hline $\begin{array}{l}\text { The teams in which lawyers work provide a supportive learning en- } \\
\text { vironment }\end{array}$ & 1 & 2 & 3 & & \\
\hline
\end{tabular}

\begin{tabular}{|l|llllll|}
\hline $\begin{array}{l}\text { PERFORMANCE APPRAISAL } \\
\text { To what extent do you disagree or agree with the fol- } \\
\text { lowing statements about the firm: }\end{array}$ & $\begin{array}{c}\text { Strongly } \\
\text { disagree }\end{array}$ & & $\begin{array}{c}\text { Strongly } \\
\text { agree }\end{array}$ \\
\hline $\begin{array}{l}\text { A lawyer's performance is appraised fully at agreed regular inter- } \\
\text { vals }\end{array}$ & 1 & 2 & 3 & 4 & 5 \\
\hline Sufficient time is allowed for proper appraisal to be provided & 1 & 2 & 3 & 4 & 5 \\
\hline $\begin{array}{l}\text { A lawyer is given clear and realizable objectives for the develop- } \\
\text { ment of skills and knowledge }\end{array}$ & 1 & 2 & 3 & 4 & 5 \\
\hline Appraisal identifies strengths and opportunities for each lawyer & 1 & 2 & 3 & 4 & 5 \\
\hline Appraisal identifies weaknesses and threats for each lawyer & 1 & 2 & 3 & 4 & 5 \\
\hline
\end{tabular}


Please describe the firm's business strategy in one sentence:

Please describe the firm's knowledge strategy in one sentence:

Please describe the firm's information technology strategy in one sentence:

Please describe the firm's human resources strategy in one sentence:

Which function in the firm is responsible for knowledge management?

function

Which function in the firm is responsible for IT management?

function 